\title{
Drugs for preventing red blood cell dehydration in people with sickle cell disease.
}

\author{
Srikanth Nagalla \\ UT Southwestern Medical Center
}

Samir K. Ballas

Thomas Jefferson University

Follow this and additional works at: https://jdc.jefferson.edu/cardeza_foundation

Part of the Hematology Commons

\section{Let us know how access to this document benefits you}

\section{Recommended Citation}

Nagalla, Srikanth and Ballas, Samir K., "Drugs for preventing red blood cell dehydration in people with sickle cell disease." (2018). Cardeza Foundation for Hematologic Research. Paper 47. https://jdc.jefferson.edu/cardeza_foundation/47

This Article is brought to you for free and open access by the Jefferson Digital Commons. The Jefferson Digital Commons is a service of Thomas Jefferson University's Center for Teaching and Learning (CTL). The Commons is a showcase for Jefferson books and journals, peer-reviewed scholarly publications, unique historical collections from the University archives, and teaching tools. The Jefferson Digital Commons allows researchers and interested readers anywhere in the world to learn about and keep up to date with Jefferson scholarship. This article has been accepted for inclusion in Cardeza Foundation for Hematologic Research by an authorized administrator of the Jefferson Digital Commons. For more information, please contact: JeffersonDigitalCommons@jefferson.edu. 


\section{(E) Cochrane Library}

Cochrane Database of Systematic Reviews

\section{Drugs for preventing red blood cell dehydration in people with sickle cell disease (Review)}

Nagalla S, Ballas SK

Nagalla S, Ballas SK.

Drugs for preventing red blood cell dehydration in people with sickle cell disease.

Cochrane Database of Systematic Reviews 2018, Issue 10. Art. No.: CD003426.

DOI: 10.1002/14651858.CD003426.pub6.

www.cochranelibrary.com 


\section{TABLE OF CONTENTS}

HEADER

ABSTRACT

PLAIN LANGUAGE SUMMARY

•. . . . . . . . . . . . . . . . . . . . . . . . . 2

SUMMARY OF FINDINGS FOR THE MAIN COMPARISON ．．．．．．．．． . . . . . . . . . . . 3

BACKGROUND . . . . . . . . . . . . . . . . . . . . . . . . . . . . . . . . . . . . . 6

OBJECTIVES . . . . . . . . . . . . . . . . . . . . . . . . . . . . . . . . . . . . .

METHODS . . . . . . . . . . . . . . . . . . . . . . . . . . . . . . . . . . . . . . 7

RESULTS . . . . . . . . . . . . . . . . . . . . . . . . . . . . . . . . . . . 9

DISCUSSION . . . . . . . . . . . . . . . . . . . . . . . . . . . . . . . . . . . 13

AUTHORS' CONCLUSIONS . . . . . . . . . . . . . . . . . . . . . . . . . . . . . . . 14

ACKNOWLEDGEMENTS . . . . . . . . . . . . . . . . . . . . . . . . . . . . . . . . . . . .

REFERENCES . . . . . . . . . . . . . . . . . . . . . . . . . . . . . . . . . . . . . . 14

CHARACTERISTICS OF STUDIES . . . . . . . . . . . . . . . . . . . . . . . . . . . . . . . . . $\quad . \quad 19$

DATA AND ANALYSES . . . . . . . . . . . . . . . . . . . . . . . . . . . . . . . . . . . . . . . . . . $\quad 27$

Analysis 1.1. Comparison 1 Anti-sickling drug versus placebo, Outcome 1 Mortality. . . . . . . . . . . . . . . $\quad 27$

Analysis 1.2. Comparison 1 Anti-sickling drug versus placebo, Outcome 2 Number of other serious sickle-related complications. . . . . . . . . . . . . . . . . . . . . . . . . 28

Analysis 1.3. Comparison 1 Anti-sickling drug versus placebo, Outcome 3 Quality of life measures. . . . . . . 28

APPENDICES . . . . . . . . . . . . . . . . . . . . . . . . . . . . . . . . . . . . . . 28

WHAT'S NEW . . . . . . . . . . . . . . . . . . . . . . . . . . . . . . . . . . . . . . . . . $\quad$. 29

HISTORY . . . . . . . . . . . . . . . . . . . . . . . . . . . . . . . . . . . . . . . . 29

CONTRIBUTIONS OF AUTHORS . . . . . . . . . . . . . . . . . . . . . . . . . . . . . . . . . 31

DECLARATIONS OF INTEREST . . . . . . . . . . . . . . . . . . . . . . . . . . . . . . . . . . . 32

SOURCES OF SUPPORT . . . . . . . . . . . . . . . . . . . . . . . . . . . . . . . . . . . 32

INDEX TERMS . . . . . . . . . . . . . . . . . . . . . . . . . . . . . . . . . . . . . 32

Drugs for preventing red blood cell dehydration in people with sickle cell disease (Review)

Copyright $\odot 2018$ The Cochrane Collaboration. Published by John Wiley \& Sons, Ltd. 


\title{
[Intervention Review]
}

\section{Drugs for preventing red blood cell dehydration in people with sickle cell disease}

\author{
Srikanth Nagalla ${ }^{1}$, Samir K Ballas ${ }^{2}$ \\ ${ }^{1}$ Division of Hematology and Oncology, UT Southwestern Medical Center, Dallas, Texas, USA. ${ }^{2}$ Cardeza Foundation for Hematologic \\ Research, Department of Medicine, Jefferson Medical College, Thomas Jefferson University, Philadelphia, USA \\ Contact address: Samir K Ballas, Cardeza Foundation for Hematologic Research, Department of Medicine, Jefferson Medical College, \\ Thomas Jefferson University, 1015 Walnut Street, Philadelphia, PA 19107-5099, USA. Samir.Ballas@jefferson.edu.
}

Editorial group: Cochrane Cystic Fibrosis and Genetic Disorders Group.

Publication status and date: New search for studies and content updated (no change to conclusions), published in Issue 10, 2018.

Citation: Nagalla S, Ballas SK. Drugs for preventing red blood cell dehydration in people with sickle cell disease. Cochrane Database of Systematic Reviews 2018, Issue 10. Art. No.: CD003426. DOI: 10.1002/14651858.CD003426.pub6.

Copyright (C) 2018 The Cochrane Collaboration. Published by John Wiley \& Sons, Ltd.

\section{A B S T R A C T}

\section{Background}

Sickle cell disease is an inherited disorder of hemoglobin, resulting in abnormal red blood cells. These are rigid and may block blood vessels leading to acute painful crises and other complications. Recent research has focused on therapies to rehydrate the sickled cells by reducing the loss of water and ions from them. Little is known about the effectiveness and safety of such drugs. This is an updated version of a previously published review.

\section{Objectives}

To assess the relative risks and benefits of drugs to rehydrate sickled red blood cells.

\section{Search methods}

We searched the Cochrane Cystic Fibrosis and Genetic Disorders Group's Haemoglobinopathies Trials Register. We also searched online trials registries for any ongoing trials (01 July 2018).

Last search of the Group's Haemoglobinopathies Trials Register: 08 October 2018.

\section{Selection criteria}

Randomized or quasi-randomized controlled trials of drugs to rehydrate sickled red blood cells compared to placebo or an alternative treatment.

\section{Data collection and analysis}

Both authors independently selected studies for inclusion, assessed study quality and extracted data.

\section{Main results}

Of the 51 studies identified, three met the inclusion criteria, including 524 people with sickle cell disease aged between 12 and 65 years of age. One study tested the effectiveness of zinc sulphate as compared to placebo and the remaining two assessed senicapoc versus placebo. No deaths were seen in any of the studies (low-quality evidence). The zinc sulphate study showed a significant reduction in painful crises (in a total of 145 participants) over one and a half years, mean difference -2.83 (95\% confidence interval -3.51 to -2.15 ) (moderate-quality evidence). However, analysis was restricted due to limited statistical data. Changes to red blood cell parameters and

Drugs for preventing red blood cell dehydration in people with sickle cell disease (Review)

Copyright ( 2018 The Cochrane Collaboration. Published by John Wiley \& Sons, Ltd. 
blood counts were inconsistent (very low-quality evidence). No serious adverse events were noted in the study. The Phase II dosefinding study of senicapoc (a Gardos channel blocker) compared to placebo showed that the high dose senicapoc showed significant improvement in change in hemoglobin level, the number and proportion of dense red blood cells, red blood cell count and indices and hematocrit value (very low-quality evidence). The results with low-dose senicapoc were similar to the high-dose senicapoc group but of lesser magnitude. There was no difference in the frequency of painful crises between the three groups (low-quality evidence). A subsequent Phase III study of senicapoc was terminated early since there was no difference observed between the treatment and control groups in the primary end point of painful crises.

\section{Authors' conclusions}

While the results of zinc for reducing sickle-related crises are encouraging, larger and longer-term multicenter studies are needed to evaluate the effectiveness of this therapy for people with sickle cell disease.

While the Phase II and the prematurely terminated phase III studies of senicapoc showed that the drug improved red blood cell survival (depending on dose), this did not lead to fewer painful crises.

Given this is no longer an active area of research, this review will no longer be regularly updated.

\section{PLAIN LANGUAGE SUMMARY}

\section{Drugs that aim to reduce the loss of water from red blood cells in people with sickle cell disease}

\section{Review question}

We reviewed the evidence to assess the relative risks and benefits of drugs to rehydrate sickled red blood cells.

\section{Background}

Sickle cell disease is an inherited condition that causes red blood cells to become sickle shaped when they lose water. This leads to a high risk of the blood vessels becoming blocked. Such blockages can cause pain, stroke and damage to organs. Recent therapies aim to stop the cells becoming sickle shaped by preventing them losing water.

\section{Search date}

The evidence is current to: 08 October 2018.

\section{Study characteristics}

The review included three studies with 524 people with sickle cell disease aged between 12 and 65 years of age. The intervention in one study was zinc sulphate and in two studies was senicapoc. Each study was compared to a placebo group (a substance which contains no medication). For each study people were selected for one treatment or the other randomly. The studies lasted from three months to 18 months.

\section{Key results}

The study with zinc sulphate showed that this drug may be able to reduce the number of sickle cell crises without causing toxic effects (low-quality evidence). There were 145 participants in this study and results showed a significant reduction in the total number of serious sickle-related crises over one and a half years, mean difference -2.83 (95\% confidence interval -3.51 to -2.15) (moderate-quality evidence). However, our analysis was limited since not all data were reported. Changes to red blood cell measurements and blood counts were not consistent (very low-quality evidence). No serious adverse events were noted in the study. The two studies with senicapoc demonstrated that this drug increases the red blood survival and has a role in preventing red blood cell dehydration in people with sickle cell disease (very low-quality evidence). The higher dose of the drug was more effective compared to the lower dose. But these changes in the red blood cells did not translate into positive clinical outcomes in terms of reduction in the number of sickle cell crises (low-quality evidence). Senicapoc had a favourable safety profile. More longer-term research is needed on these drugs and others that might prevent water loss in red blood cells.

Given this is no longer an active area of research, this review will no longer be regularly updated.

\section{Quality of the evidence}

The quality of the evidence was mixed across outcomes.

Drugs for preventing red blood cell dehydration in people with sickle cell disease (Review)

Copyright ( 2018 The Cochrane Collaboration. Published by John Wiley \& Sons, Ltd. 


\section{SUMMARY OF FINDINGS FOR THE MAIN COMPARISON [Explanation]}

\section{Drugs to prevent red blood cell dehydration compared with placebo for sickle cell disease}

Patient or population: adults and children with sickle cell disease

Settings: outpatients

Intervention: drugs to prevent red blood cell dehydration (anti-sickling treatment)

Comparison: placebo

\begin{tabular}{|c|c|c|c|c|c|c|}
\hline \multirow[t]{3}{*}{ Outcomes } & \multicolumn{2}{|c|}{ Illustrative comparative risks* $(95 \% \mathrm{Cl})$} & \multirow[t]{3}{*}{$\begin{array}{l}\text { Relative effect } \\
(95 \% \mathrm{Cl})\end{array}$} & \multirow[t]{3}{*}{$\begin{array}{l}\text { No of Participants } \\
\text { (studies) }\end{array}$} & \multirow[t]{3}{*}{$\begin{array}{l}\text { Quality of the evidence } \\
\text { (GRADE) }\end{array}$} & \multirow[t]{3}{*}{ Comments } \\
\hline & Assumed risk & Corresponding risk & & & & \\
\hline & Placebo & Anti-sickling drug & & & & \\
\hline $\begin{array}{l}\text { Number of deaths } \\
\text { Follow-up: } 12 \text { weeks to } \\
18 \text { months }\end{array}$ & \multicolumn{3}{|c|}{ No deaths were seen in any of the studies in either group. } & $\begin{array}{l}524 \\
(3)\end{array}$ & $\begin{array}{l}\oplus \oplus \bigcirc \bigcirc \\
\text { low }^{1,2}\end{array}$ & \\
\hline $\begin{array}{l}\text { Number of sickle pain } \\
\text { crises } \\
\text { Follow-up: } 12 \text { weeks to } \\
18 \text { months }\end{array}$ & \multicolumn{3}{|c|}{$\begin{array}{l}\text { There was no significant difference in the rate of the sickle cell painful } \\
\text { crises between the senicapoc and placebo groups in either study (Ataga } \\
\text { 2008; Ataga 2011). } \\
\text { There were } 1.40 \text { and } 3.38 \text { painful crises per participant in the zinc and } \\
\text { control groups respectively (Gupta 1995). }\end{array}$} & $\begin{array}{l}524 \\
(3)\end{array}$ & $\begin{array}{l}\oplus \oplus \bigcirc \bigcirc \\
\text { low }^{1,2}\end{array}$ & $\begin{array}{l}\text { No data were available } \\
\text { to enter into the analy- } \\
\text { sis for any of the three } \\
\text { studies } \\
\text { In the Gupta study, SDs } \\
\text { could not be calculated } \\
\text { from the data provided } \\
\text { in the publication (Gupta } \\
\text { 1995). } \\
\text { The } 2011 \text { Ataga study } \\
\text { was terminated early } \\
\text { and so there were few } \\
\text { participants that com- } \\
\text { pleted treatment and du- } \\
\text { ration of treatment var- } \\
\text { ied (Ataga 2011). }\end{array}$ \\
\hline
\end{tabular}


Number of serious MD between the groups for the number of other sickle-related compli- 145 complications of sickle cations, MD $-2.83(95 \% \mathrm{Cl}-3.51$ to -2.15$)$ in favour of the anti-sickling (1) cell disease: mean treatment (Gupta 1995)

moderate $^{3}$ $=8.20(\mathrm{P}<0.00001)$

number of crises

Follow-up: 18 months

Red blood cell dehydra- High and low doses of senicapoc resulted in a significant decrease 524

tion

in the percentage of dense red blood cells compared to the placebo (3)

Follow-up: 12 weeks to (Ataga 2008). There was a significant decrease in the MCV and MCH in

18 months

the high-dose senicapoc group compared to the placebo. The low-dose senicapoc caused a significant reduction in the MCH but not MCV when compared to the placebo. There was no significant difference in $\mathrm{MCHC}$ between the 2 intervention arms and the placebo arm

The Gupta paper reported significant improvements in laboratory parameters of red blood cell dehydration (hemoglobin, reticulocyte count, serum bilirubin and serum zinc level) in the intervention group (Gupta 1995).

Quality of life: Days of MD between the groups for the number of days of work lost per crisis, 145 work lost per crisis MD $-1.50(95 \% \mathrm{Cl}-2.24$ to -0.76$)$ in favour of the anti-sickling treatment (1)

Follow-up: 18 months

(Gupta 1995)

\section{5}

$\oplus \oplus \oplus \bigcirc$

moderate ${ }^{3}$

$\oplus 000$

very low 4,5

Number of other sickle- One study showed no difference in other sickle-related events between related events:

Follow-up: 12 weeks to

18 months

0
anti-sickling treatment and placebo (Ataga 2008).
(1) $\oplus \oplus \bigcirc \bigcirc$

Iow ${ }^{1,2}$

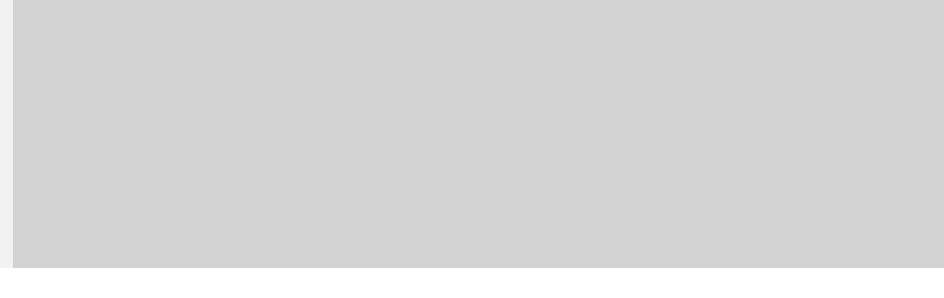

There were no data available to enter into analysis and we have presented the results narratively 
*The basis for the assumed risk (e.g. the median control group risk across studies) is provided in footnotes. The corresponding risk (and its $95 \%$ confidence interval) is based on the assumed risk in the comparison group and the relative effect of the intervention (and its $95 \% \mathrm{Cl}$ ).

Cl: confidence interval; $\mathbf{M C H}$ : mean corpuscular hemoglobin; MCHC: mean corpuscular hemoglobin concentration; MCV: mean corpuscular volume; M D: mean difference; RR: risk ratio; SD: standard deviation.

GRADE Working Group grades of evidence

High quality: further research is very unlikely to change our confidence in the estimate of effect.

Moderate quality: further research is likely to have an important impact on our confidence in the estimate of effect and may change the estimate.

Low quality: further research is very likely to have an important impact on our confidence in the estimate of effect and is likely to change the estimate.

Very low quality: we are very uncertain about the estimate.

1. Downgraded once due to low event rates causing imprecision.

2. Downgraded once due to risk of bias from one study being terminated early and participants receiving treatment for different durations.

3. Downgraded once due to risk of bias within the single study. Little information was given regarding baseline characteristics making it difficult to ascertain if the groups were sufficiently similar at the start of the study.

4. Downgraded twice due to risk of bias from one study being terminated early and participants receiving treatments for different durations and one study giving little information on baseline characteristics and numbers in each arm.

5. Downgraded once due to imprecision as no data were available to analyse and only narrative results could be included. 


\section{B A C K G R O U N D}

\section{Description of the condition}

Sickle cell disease is caused by the inheritance from both parents of a mutation in the beta-globin gene. The different types of the disease (e.g. SS, SC, S $\beta$ Thal) are caused by inheritance of different altered beta-globin genes, and this can be diagnosed with blood tests or genetic testing. It is so named because the red blood cells (erythrocytes) become distorted into unusual shapes when they give up the oxygen they carry, due to polymerisation of the abnormal hemoglobin within. This is accelerated by a cycle of red blood cell dehydration, which increases intracellular concentration of the sickle hemoglobin and hence polymerisation. One of the distinguishing features of sickle cell anemia is the presence of these dense, dehydrated red blood cells, which are easily destroyed and can mesh together to block blood vessels (vaso-occlusion).

The disease is characterised by episodes of anemia, vaso-occlusive crises and organ damage, with symptoms which are unpredictable and differ between individuals (Serjeant 1992). It is most prevalent in populations originating from sub-Saharan Africa and parts of India; although population movement has made it a worldwide problem, with approximately 60,000 African-American and 10,000 British people with the disease (Davies 1997; Hickman 1999). Clinical management centers around prophylaxis against infection, pain relief, hydration and periodic blood transfusion in many people to reduce the concentration of sickle cells in the blood stream. However, most treatment is symptomatic and, as a result, despite vastly improving care services, many people with the disease still die in childhood due to sudden bouts of infection, stroke, acute chest syndrome or splenic sequestration (Leikin 1989). Clearly preventative measures would be preferable.

\section{How the intervention might work}

In an attempt to prevent the increased concentration of sickle hemoglobin (which causes polymerisation and deformation of the red blood cell), recent research has begun to target the physiological process leading to dehydration of the erythrocyte for therapeutic potential. Red blood cells are thought to undergo dehydration via two kinetically distinct pathways, a "fast track" process in reticulocytes (immature red blood cells), and a slow process involving mature erythrocytes. Dehydration via either pathway is due to the water loss accompanying primary loss from the cell of potassium and chloride ions. The major routes involved in sickle cell dehydration are the calcium-activated potassium channel (Gardos channel) operating in parallel with the conductive chloride pathway and the electroneutral potassium-chloride co-transporter(s) (Brugnara 1995). Potential therapeutic approaches involve the use of drugs that reduce sickle cell dehydration via a block of these mechanisms.
The first route, and perhaps the most promising for therapy, is the Gardos channel. Upon deoxygenation of the sickle cell, potassium and water loss are induced as free intracellular calcium levels rise, possibly due to increased membrane permeability for calcium. The Gardos channel may also be positively modulated by vaso-active molecules such as endothelins (Rivera 2000). Studies both in a mouse model for sickle cell disease (SAD mouse) and in humans have shown that this channel can be selectively inhibited by a group of drugs known as the imidazole antimycotics, including the anti-fungal agent clotrimazole (Brugnara 1993; Brugnara 1996; de Franceschi 1994) and a related compound Senicapoc (ICA-17043) (Stocker 2000). Blocking of the Gardos channel resulted in increased potassium content and improved hydration of erythrocytes. Senicapoc (bis(4-fluorophenyl)phenyl acetamide) is a selective and potent blocker of the Gardos channel (Stocker 2003). Dimethyl adipimate may also have an anti-sickling role via the Gardos channel (Gibson 2000).

The role of the chloride conductance or exchange system in sickle cell dehydration has also been recently explored. In vitro, loss of potassium from deoxygenated human sickle cells could be limited by the reversible anion conductance inhibitor NS1652 (Bennekou 2000). Further, the related compound, NS3623 (Bennekou 2001), which has a greater half-life in vivo, improved hydration in the SAD mouse.

Potassium-chloride co-transport occurs via a different membrane protein, which is activated by acidity within the cell allowing loss of potassium and water. This is seen almost exclusively in reticulocytes. No drugs have been found to be useful in inhibiting the transporter, but it has been shown that divalent cations, such as magnesium ions (Brugnara 1987), can block the pathway, again protecting against dehydration. Magnesium preparations are currently marketed for treatment of constipation, boils, recurrence of seizures in eclampsia, renal failure and are recommended for emergency treatment of serious arrhythmias. Magnesium pidolate has been investigated in combination with hydroxyurea in a Phase I trial (Hankins 2008).

Other strategies have also been suggested for reducing sickle red blood cell dehydration. These include a transmembrane sodiumpotassium pump mechanism which is partly responsible for increased ion permeability on deoxygenation. While this is thought to be a minor contributor to dehydration, dipyridamole has been shown to be a selective inhibitor of passive ion transfer and there is rationale, including the known effects on platelet and endothelial cell function, for testing its efficacy in sickle cell disease. Oxidative damage to the cell membrane, which can occur in sickle cell disease due to abnormal iron deposits, increases loss of potassium and water contributing to red blood cell dehydration (Brugnara 1995). Oral iron chelators may help in this case, and antioxidants could also be useful (Gibson 1998). Nitric oxide, an endogenous compound which is thought to be an important regulator of smooth muscle tone and vasodilatation, is reduced in people with sickle 
cell disease (Qureshi 2000). Preliminary studies in SAD mice have shown that it can reduce red blood cell dehydration (Adrie 2000), and oral supplementation with arginine, an amino acid which releases nitric oxide, ( $5 \%$ by weight) also induces a decrease in red blood cell density (Romero 2000), via Gardos channel activity (Romero 2002). Hydroxyurea, an anti-cancer compound proven to reduce sickle-related events (Charache 1995; Jones 2001), improves the hydration status of sickle red blood cells (Ballas 1989), although it is not clear whether this is a direct effect, or a consequence of increased levels of fetal hemoglobin (HbF).

In Brazil a local plant, Pfaffia paniculata, has been anecdotally reported to ameliorate clinical symptoms of sickle cell disease. The plant possibly contains a naturally occurring compound, which acts as a sodium ionophore. In vitro studies have shown increased erythrocyte deformability and sodium content of sickle red blood cells when treated with it, thus potentially rehydrating sickle cells (Ballas 2000).

Piracetam (2-oxo-1-pyrrolidine acetamide), a derivative of the neurotransmitter gamma-aminobutyric acid (GABA), works primarily in neurotransmission, but appears to have a beneficial effect on red blood cell rheology and thus able to reduce vaso-occlusive crises in people with sickle cell disease. The exact mechanism of this remains unclear. It does not appear to inhibit the Gardos channel as previously reported (Gini 1987; Stone 1988; Stuart 1990; Stuart 1992). The use of piracetam for reducing the incidence of painful sickle cell disease crises is the subject of another Cochrane Review (Al Hajeri 2007).

\section{Why it is important to do this review}

All of these potential therapies look promising for reducing dehydration of red blood cells, and therefore ameliorating the symptoms of sickle cell disease. This review aims to bring together clinical trials in this area to establish the clinical value of this pharmaceutical approach.

This is an update of previously published versions of the review (Nagalla 2010; Nagalla 2012; Riddington 2002; Singh 2007).

\section{O B J E C T IVES}

To determine whether pharmaceutical therapies designed to prevent red blood cell dehydration in sickle cell disease:

1. reduce mortality;

2. reduce sickle cell vaso-occlusive crises including episodes of pain and stroke;

3. reduce other complications associated with sickle cell disease, e.g. acute chest syndrome, infection, anemia, splenic sequestration, organ damage;
4. are associated with unacceptable adverse events.

\section{METHODS}

\section{Criteria for considering studies for this review}

\section{Types of studies}

Randomized or quasi-randomized trials. Trials in which quasirandomized methods, such as alternation, are used were included if there was sufficient evidence that the treatment and control groups were similar at baseline.

\section{Types of participants}

People with known sickle cell disease (SS, SC, $\mathrm{S} \beta+$ and $\mathrm{S} \beta 0$, proven by electrophoresis and sickle solubility test, with family studies or DNA tests as appropriate) of all ages and both sexes, in any setting.

\section{Types of interventions}

Pharmaceutical therapies designed to reduce red blood cell dehydration to prevent vaso-occlusive events in sickle cell disease compared to comparator interventions. Studies which included antisickling drugs for which the exact mechanism of action is not known were considered if there was some evidence that they act via the red blood cell membrane to prevent sickling. Piracetam was excluded since there is insufficient evidence that it acts primarily via the red blood cell membrane to improve red blood cell rheology. Hydroxyurea was excluded as the primary mechanism for this drug is through increasing foetal hemoglobin. Studies in which the intervention was given only to treat an existing sicklerelated event were excluded.

\section{Types of outcome measures}

While the interventions should, by definition, decrease dense sickled cells by reducing erythrocyte dehydration, such biochemical parameters were examined separately from clinical outcomes, to determine the effectiveness of the interventions in clinical practice. However, the hematological outcomes may also provide an indication of the efficacy, and potential effectiveness, of treatment, so these were also analyzed.

\section{Primary outcomes}

1. Number of deaths

2. Number of sickle pain crises (requirement for opiate treatment or self-reported patient scales) 
3. Number of serious complications of sickle cell disease including stroke, acute chest syndrome and acute splenic sequestration

\section{Secondary outcomes}

1. Red blood cell dehydration (proportion of dense cells, mean corpuscular hemoglobin concentration (MCHC), mean corpuscular volume (MCV))

2. Full blood count including hemoglobin, white blood cell and platelet counts, sickle cell hemoglobin $(\mathrm{HbS})$ and foetal hemoglobin $(\mathrm{HbF})$ level

3. Quality of life: days off work or school, hospitalisations, mobility, etc.

4. Number of other sickle-related events, including priapism, leg ulceration

\section{Other outcomes}

1. Any reported adverse effects or toxicity of drugs were recorded

\section{Search methods for identification of studies}

There were no restrictions regarding language or publication status.

\section{Electronic searches}

Relevant studies were identified from the Cystic Fibrosis \& Genetic Disorders Review Group's Haemoglobinopathies Trials Register using the terms: (sickle cell OR (haemoglobinopathies AND general)) [kw] AND (dehydration [kw,ti,ab] OR (anti-sickling OR crisis) $[\mathrm{kw}])$

The Haemoglobinopathies Trials Register is compiled from electronic searches of the Cochrane Central Register of Controlled Trials (CENTRAL) (updated each new issue of the Cochrane Library) and weekly searches of MEDLINE. Unpublished work is identified by searching the abstract books of five major conferences: the European Haematology Association conference; the American Society of Hematology conference; the British Society for Haematology Annual Scientific Meeting; the Caribbean Public Health Agency Annual Scientific Meeting (formerly the Caribbean Health Research Council Meeting); and the National Sickle Cell Disease Program Annual Meeting. For full details of all searching activities for the register, please see the relevant section of the Cochrane Cystic Fibrosis and Genetic Disorders Group's website.

Date of the most recent search of the Group's Haemoglobinopathies Trials Register: 08 October 2018.

We also searched the World Health Organization (WHO) International Clinical Trials Registry Platform ( ICTRP) ( apps.who.int/ trialsearch/) and ClinicalTrials.gov ( www.ClinicalTrials.gov) for any ongoing trials (01 July 2018) (Appendix 1).

\section{Searching other resources}

The bibliographic references of all retrieved literature were reviewed for additional reports of studies.

\section{Data collection and analysis}

\section{Selection of studies}

Two authors independently applied the inclusion criteria in order to select studies for inclusion in the review. If disagreement arose on the suitability of a study for inclusion in the review, the authors reached consensus by discussion.

\section{Data extraction and management}

Two authors independently extracted the data. Each author, using standard data acquisition forms, independently extracted data. If disagreement arose on the study quality, the authors reached a consensus by discussion.

We planned to collect data at monthly time-frames. However, if data were reported at other time periods we planned to consider examining these as well.

\section{Assessment of risk of bias in included studies}

Two authors assessed the risk of bias of each study. In particular, authors examined details of the randomization method, allocation concealment, whether the study was blinded, whether intentionto-treat analyses were possible from the available data and if the number of participants lost to follow up or subsequently excluded from the study was recorded.

\section{Measures of treatment effect}

We recorded dichotomous outcomes e.g. life or death, as present or absent, whilst recording continuous data such as organ function tests as either mean change from baseline for each group or mean post treatment values and standard deviation (SD) for each group. We aimed to calculate a pooled estimate of the treatment effect for each outcome across studies, (for binary outcomes the odds of an outcome among treatment allocated participants to the corresponding odds among controls).

\section{Unit of analysis issues}

Cross-over trials will only be included in future versions of this review if we consider there to be a sufficient washout period between the treatment arms. We will analyze any data from such trials according to methods described by Elbourne (Elbourne 2002). 


\section{Dealing with missing data}

We sought full reports from authors where studies have been published in abstract form, presented at meetings or reported to the co-authors. Where information was missing or unclear, we contacted the primary investigator.

In order to allow an intention-to-treat analysis, we grouped data by allocated treatment groups, irrespective of later exclusion (regardless of cause) or loss to follow up.

\section{Assessment of heterogeneity}

We will test for heterogeneity between studies using a standard chi-squared test and $\mathrm{I}^{2}$ statistic (Higgins 2003). We will use the following ranges to describe heterogeneity:

- $0 \%$ to $40 \%$ : might not be important;

- $30 \%$ to $60 \%$ : may represent moderate heterogeneity;

- $50 \%$ to $90 \%$ : may represent substantial heterogeneity;

- $75 \%$ to $100 \%$ : considerable heterogeneity.

\section{Assessment of reporting biases}

Comprehensive searches were done by both the authors to minimize publication and reporting biases. We compared the 'Methods' section of the full published paper to the 'Results' section to ensure that all outcomes which were measured, were reported.

\section{Data synthesis}

We have used fixed-effect analysis with the data we have presented. If there is a high or moderate degree of heterogeneity between studies included in any future updates, we will consider using a random-effects analysis.

\section{Subgroup analysis and investigation of heterogeneity}

If we find heterogeneity between studies, examination of subgroups, such as age of participants, type of sickle cell disease or ethnicity, may help to explain the reasons for this.

For future updates, where appropriate, we plan to perform subgroup analysis of different drugs or combinations of drugs to examine their relative risks and benefits.

\section{Sensitivity analysis}

If we include a sufficient number of studies where quasi-randomization methods are used, we will analyze this group separately.

\section{Summary of findings tables}

In a post hoc change, we have presented a summary of findings table (Summary of findings table 1).

All seven outcomes were included:

1. Number of deaths
2. Number of sickle pain crises (requirement for opiate treatment or self-reported patient scales)

3. Number of serious complications of sickle cell disease including stroke, acute chest syndrome and acute splenic sequestration

4. Red blood cell dehydration (proportion of dense cells, mean corpuscular hemoglobin concentration (MCHC), mean corpuscular volume (MCV))

5. Full blood count including hemoglobin, white blood cell and platelet counts, sickle cell hemoglobin ( $\mathrm{HbS})$ and foetal hemoglobin $(\mathrm{HbF})$ level

6. Quality of life: days off work or school, hospitalisations, mobility, etc.

7. Number of other sickle-related events, including priapism, leg ulceration

We determined the quality of the evidence using the GRADE approach; and downgraded evidence in the presence of a high risk of bias in at least one study, indirectness of the evidence, unexplained heterogeneity or inconsistency, imprecision of results, high probability of publication bias. We downgraded the evidence by one level if we considered the limitation to be serious and by two levels if very serious.

\section{RE S U L T S}

\section{Description of studies}

\section{Results of the search}

We identified 232 references and discarded 163 references as they were not relevant to the review. We further assessed 69 references (to 51 studies) and included three studies within the review (Ataga 2008; Ataga 2011; Gupta 1995) and excluded the remaining 48 studies.

\section{Included studies}

\section{Trial design}

All three studies were described as double-blind, randomized placebo-controlled studies (Ataga 2008; Ataga 2011; Gupta 1995). The Phase II Ataga study was a dose-finding study which compared a $10 \mathrm{mg}$ dose of senicapoc to a $6 \mathrm{mg}$ dose of senicapoc or to placebo. The trial was multicenter (19 medical centers) in the USA (Ataga 2008). The study treated participants for 12 weeks (Ataga 2008).The more recent senicapoc trial was a Phase III trial was conducted across 75 centers in 6 countries (Ataga 2011). The participants were randomized to senicapoc $(20 \mathrm{mg}$ twice daily as 
a loading dose for 4 days followed by $10 \mathrm{mg}$ daily) or placebo in a 1:1 fashion. The treatment phase consisted of 52 weeks followed by a follow-up period of 8 weeks (Ataga 2011). The Gupta trial compared oral zinc ( $220 \mathrm{mg}$ three times a day) to placebo. The trial was from a single center in India (Gupta 1995). The Gupta study lasted for one and a half years; participants were seen weekly but data were analysed at the end of the follow-up period (Gupta 1995).

\section{Participants}

There were 524 participants with sickle cell disease included in the review. The Phase II senicapoc study randomized 90 participants aged between 18 to 60 years (Ataga 2008). The Phase III senicapoc study randomized 297 participants between the ages of 16 and 65 years, but only the 289 participants in the modified intentto-treat group (participants who received at least one dose of the drug) were included in this review (Ataga 2011). In the remaining study, Gupta randomized 145 participants aged between 12 to 27 years (Gupta 1995).

In the Phase II senicapoc study, participants had at least one episode of sickle cell-related painful crisis four weeks prior to the study screening and participants taking hydroxyurea had to be on a stable dose of the drug for at least three months prior to their enrolment in the study (Ataga 2008). In the Phase III senicapoc study, participants had at least two episodes of painful crisis within the preceding 12 months that required medical attention (Ataga 2011). Participants on hydroxyurea in preceding 12 months were required to be on a stable dose of the drug prior to inclusion in the study (Ataga 2011). Gupta excluded participants under five years of age or those who had a history of chronic persistent infection, evidence of organ failure, exposure to extreme temperatures or were taking other medication (Gupta 1995).

In the Phase II senicapoc study, all the participants who received at least one week of the drug and underwent the initial efficacy analysis were included in the modified intent-to-treat analysis. Eightyeight participants met this criteria and only two discontinued the study before the initial efficacy analysis (Ataga 2008). In the Phase III senicapoc study 289 participants from the initial group of 297 were included in the modified intent-to-treat analysis based on participants who received at least one dose of the drug (Ataga 2011). However, in the Gupta study, 15 participants out of the original 145 subsequently dropped out or were lost to follow-up, and these were not included in the analysis (Gupta 1995).

\section{Interventions}

The Phase II senicapoc study compared three groups: high-dose senicapoc (single $150 \mathrm{mg}$ loading dose followed by $10 \mathrm{mg}$ daily maintenance dose); or low-dose senicapoc (single $100 \mathrm{mg}$ loading dose followed by $6 \mathrm{mg}$ daily maintenance dose); or placebo (Ataga 2008). The high-dose senicapoc group had 31 participants, the low-dose senicapoc and placebo groups had 29 and 30 participants assigned respectively. The Phase III senicapoc study stratified participants based on concomitant hydroxyurea therapy. In each of these groups participants were randomized to receive senicapoc (loading dose of $20 \mathrm{mg}$ twice daily for four days followed by $10 \mathrm{mg}$ daily) or placebo in a 1:1 fashion. Out of the 289 participants in the modified intent-to treat analysis, there were 163 participants in the hydroxyurea group and 126 in the non-hydroxyurea group. The hydroxyurea group had 84 participants receiving senicapoc and 79 participants on placebo. The non-hydroxyurea group had 61 senicapoc participants and 65 in the placebo group (Ataga 2011). The third study randomized participants to receive either zinc sulphate $(220 \mathrm{mg}$ three times a day orally) or an identical placebo (Gupta 1995).

\section{Outcomes measured}

The Ataga Phase II study reported the effect of senicapoc on hemoglobin levels, red blood cell (RBC) indices, markers of hemolysis and painful crises. The primary end point of the study was the change in hemoglobin level with the secondary end points being changes in the number and proportion on the dense red blood cells (RBCs) and reticulocytes, lactate dehydrogenase, indirect bilirubin, $\mathrm{RBC}$ count, $\mathrm{RBC}$ indices, hematocrit and frequency of painful crises (Ataga 2008). The primary end point in the Ataga Phase III was the frequency of sickle cell pain crises. TIme to the first, second and third acute painful crises was a secondary end point of the study (Ataga 2011). The effect of the drug on markers of hemolysis, hemoglobin, hematocrit, reticulocyte count, red blood cell count and dense erythrocytes were also measured. The Gupta study measured the number of sickle-related crises, and the number of days in hospital and working (or school) days lost for each crisis (Gupta 1995).

\section{Excluded studies}

Forty-eight studies were excluded. Reasons for exclusions were a lack of evidence that they were acting primarily on red blood cell dehydration pathways, or they were being used to treat a sicklerelated crisis, rather than preventing it, or the study was not randomized (see Characteristics of excluded studies table). Studies on piracetam were excluded since there is insufficient evidence that this drug acts primarily via the red blood cell membrane to improve red blood cell rheology (Alvim 2005; Piracetam Study 1998).

\section{Risk of bias in included studies}

\section{Allocation}

All three studies were judged to have a low risk of bias for the generation of the allocation sequence (Ataga 2008; Ataga 2011; Gupta 1995). In both of the senicapoc studies an integrated voice 
response system was used in the centralized randomization protocol (Ataga 2008; Ataga 2011). In the zinc study, New Castle software was used to generate randomization (Gupta 1995).

Both the senicapoc studies and the zinc study did not report on allocation concealment and so all studies were judged to have an unclear risk of bias for this criteria (Ataga 2008; Ataga 2011; Gupta 1995).

\section{Blinding}

Both the participants and treating physicians were blinded in all three studies and so were judged to have a low risk of bias (Ataga 2008; Ataga 2011; Gupta 1995). Additionally, Ataga reported that the review committee were also blinded (Ataga 2008).

\section{Incomplete outcome data}

In the senicapoc Phase II study, a modified intent-to-treat population was used in the efficacy analysis (Ataga 2008). Two out of the the 90 participants dropped out prior to the initial assessment and so 88 participants were included as a part of the modified intentto-treat population. The safety analysis included all the 90 participants. A total of 10 participants did not complete the study; full reasons for this were given in the published paper and we therefore judged there to be a low risk of bias due to incomplete outcome data (Ataga 2008).

The Phase III senicapoc study was terminated early due to a lack of efficacy as determined by the unblinded Data Monitoring Committee (Ataga 2011). The reasons for the Committee's decision were based on the fact that there was no significant improvement in the rate of sickle cell painful crises in participants treated with senicapoc compared to those on placebo $(\mathrm{P}=0.38$ versus $\mathrm{P}=$ 0.31 respectively) despite improvements in anemia and hemolysis. Moreover, comparisons of the times to first, second and third crises between the senicapoc and placebo groups were not significantly different. The authors suggest that the increase in $\mathrm{Hb}$ level caused an increase in blood viscosity and offset the potential benefits of senicapoc with regards to painful crises. Furthermore, due to the early termination of the study, the duration that the drug was administered was different in the participants who stopped treatment early. Given these facts, we have not entered any data from this trial into the data tables and results are reported narratively.

In the zinc study, a power calculation, which assumed $40 \%$ control event rate and $20 \%$ response, found that 130 participants were needed. Fifteen, of the 145 participants recruited, dropped out or were lost to follow-up, and these are not accounted for in the study publication (Gupta 1995). We therefore judge there to be an unclear risk of bias from reported outcome data for this study.

\section{Selective reporting}

In both the senicapoc studies and the zinc study, all outcomes stated in 'Methods' section were reported in the 'Results' section of the papers; therefore there is a low risk of bias for selective reporting for all studies (Ataga 2008; Ataga 2011; Gupta 1995).

\section{Other potential sources of bias}

The participants in the Phase II senicapoc study were evenly matched in terms of their baseline characteristics between the three study arms (Ataga 2008) and this was also true for the Phase III senicapoc study (Ataga 2011). There was no significant difference in the mean age, sex and the hospitalizations in the year prior to the enrolment in the study. We therefore judged both studies to have a low risk of bias for this domain.

The zinc study gave little information regarding baseline characteristics, including disease severity and medical history of participants, making it difficult to ascertain if the groups were sufficiently similar at the start of the study (Gupta 1995). Thus currently we judge there to be an unclear risk of bias for this study.

\section{Effects of interventions}

See: Summary of findings for the main comparison

\section{Primary outcomes}

\section{Number of deaths}

No treatment related deaths were reported in the included studies (low-quality evidence) (Analysis 1.1) (Ataga 2008; Ataga 2011; Gupta 1995).

\section{Number of pain crises}

No data were available to enter into the analysis for any of the three studies (low-quality evidence) (Gupta 1995; Ataga 2008; Ataga 2011)

In the senicapoc Phase II study there were a total of 15 sickle cell crises, with the events being distributed equally between the placebo and the two intervention arms (five in each) (Ataga 2008). So both the lower $(6 \mathrm{mg})$ and higher doses $(10 \mathrm{mg})$ of senicapoc did not help in the reduction of painful crises compared to placebo. The Phase III senicapoc study was terminated prematurely as it was unlikely to meet the primary endpoint (Ataga 2011). There was no significant difference in the rate of the sickle cell painful crises between the senicapoc and placebo groups $(0.38$ versus $0.31, \mathrm{P}=$ $0.054)$. There was no difference in the painful crises rate between the two treatment arms in the hydroxyurea group (0.39 versus $0.33, \mathrm{P}=0.483$ ) but the rate of painful crises was significantly higher in the senicapoc group compared to the placebo group in participants not on hydroxyurea $(0.37$ versus $0.29, \mathrm{P}=0.037)$ (Ataga 2011). The study included pain-only crises, acute chest syndrome, hepatic sequestration, priapism and stroke under the primary end point of sickle cell-related pain crises. Given that the 
study was terminated prematurely, there are very few participants who completed the treatment. The duration of the drug regimen was different in the participants who stopped treatment. Therefore we have not included any data from this trial in the data analysis table.

In the zinc study there were 91 vaso-occlusive crises in the intervention group, compared to 220 in the control group (Gupta 1995). This amounts to, on average, 1.40 and 3.38 painful crises per participant in intervention and control groups respectively. Standard deviations cannot be calculated from the data provided in the publication, so we are attempting to contact the authors, and hope to provide this information in a future update.

\section{Number of other serious sickle-related complications}

In the Phase II senicapoc study, there were two episodes of pneumonia and one episode of bronchitis in the placebo group (Ataga 2008). There was one episode of pneumonia in each of the intervention arms. There was a single episode of acute chest syndrome in the study and it occurred in the $6 \mathrm{mg}$ (low-dose) senicapoc arm. There was one episode of aseptic necrosis of the bone in the lowdose senicapoc arm and one episode of deep venous thrombosis in the high-dose senicapoc arm. Furthermore, there was one episode of staphylococcal sepsis in the low-dose senicapoc group and one urinary tract infection in the high-dose senicapoc group. The only case of deep vein thrombosis was reported in the high-dose senicapoc group (Ataga 2008).

The Phase III senicapoc study included pain-only crises, acute chest syndrome, hepatic sequestration, priapism and stroke under the primary end point of sickle cell-related pain crises (Ataga 2011).

In the zinc study, altogether there were 160 episodes of sicklerelated crises in the intervention group, and 344 in the control group (Gupta 1995). Of these, vaso-occlusive crises accounted for $59 \%$ in the intervention group and $64 \%$ in the control group, mixed crises for $24 \%$ and $20 \%$ in the intervention and control groups respectively, $9 \%$ and $12 \%$ were hemolytic, $1 \%$ in each group sequestration and $1 \%$ in each group had aplastic crises. The mean number of all sickle-related crises in the intervention group was 2.46 (SD 1.04), compared to 5.29 (SD 2.58), in the control group. The MD between groups was -2.83 (95\% CI -3.51 to 2.15 ), showing a statistically significant reduction in the participants treated with zinc (moderate-quality evidence) (Analysis 1.2) (Gupta 1995).

\section{Secondary outcomes}

\section{Red blood cell dehydration}

All three studies presented information on this outcome (very lowquality evidence) (Gupta 1995; Ataga 2008; Ataga 2011).

Both the high and low doses of senicapoc resulted in a significant decrease in the percentage of dense red blood cells compared to the placebo (Ataga 2008). The magnitude of decrease was higher with the $10 \mathrm{mg}$ senicapoc compared to the $6 \mathrm{mg}$ senicapoc. There was a significant decrease in the MCV and mean corpuscular hemoglobin $(\mathrm{MCH})$ in the high-dose senicapoc group compared to the placebo. The low-dose senicapoc caused a significant reduction in the $\mathrm{MCH}$ but not MCV when compared to the placebo. There was no significant difference in MCHC between the two intervention arms and the placebo arm. The biochemical markers of hemolysis like lactate dehydrogenase and indirect bilirubin were significantly lower in the senicapoc groups compared to the placebo group. The magnitude of the change was dependent on the dose of senicapoc.

The findings seen in the Phase II senicapoc study were confirmed in the Phase III study where senicapoc was compared to a placebo (Ataga 2011).

The Gupta paper reported significant improvements in laboratory parameters of red blood cell dehydration (hemoglobin, reticulocyte count, serum bilirubin and serum zinc level) in the intervention group (Gupta 1995).

\section{Full blood count}

The senicapoc study demonstrated an increase in the hemoglobin level by $0.68 \mathrm{gm} / \mathrm{dL}$ in the high-dose senicapoc group compared to the $0.01 \mathrm{gm} / \mathrm{dL}$ increase in the placebo group $(\mathrm{P}<0.001)$ (Ataga 2008). There was no significant change in the hemoglobin level when $6 \mathrm{mg}$ of senicapoc was compared to the placebo. There was significant increase in the RBC count with senicapoc compared to the placebo in a dose-dependent manner.

Both the high and low doses of senicapoc resulted in a significant decrease in the percentage and absolute number of reticulocytes (Ataga 2008).

The above findings were confirmed in the Phase III senicapoc study. There was no significant change in the HbF levels (Ataga 2011).

Gupta reported that participants in the intervention group had a mean hemoglobin level of $7.9 \mathrm{~g} / \mathrm{dL}$ compared to $6.8 \mathrm{~g} / \mathrm{dL}$ in the control group $(\mathrm{P}<0.01)$ (Gupta 1995). Other outcomes were not reported, and SDs were not given. Again, the authors will be contacted to clarify this information.

\section{Quality of life measures}

These measures were not assessed in the Phase II study of senicapoc (Ataga 2008).

In the Phase III senicapoc study there was no difference in the FACIT-Fatigue scores between the two treatment arms irrespective of the hydroxyurea stratification. Similarly, there was no difference in the number of participants transfused, the number of transfusions or units per participant. The participants on senicapoc spent more days in the hospital compared to those on placebo (Ataga 2011). 
Gupta reported the mean length of hospital stay per crisis in the intervention and control groups respectively was 4.3 and 3.9 days, MD 0.40 (95\% CI -0.28 to 1.06 ), with no significant difference (Analysis 1.3) (Gupta 1995). Days of work lost per crisis were 3.4 in the zinc group and 4.9 in the control group. Although there is a significant reduction in the number of work days lost in the zinc group, MD -1.50 (95\% CI -2.24 to -0.76 ), on average hospital stay was longer in this group (moderate-quality evidence) (Analysis $1.3)$.

\section{Other sickle-related events}

In the Phase II senicapoc study (low-quality evidence), there was one episode of staphylococcal sepsis in the low-dose senicapoc group and one urinary tract infection in the high-dose senicapoc group (Ataga 2008). There was one report of muscle strain in the high-dose senicapoc group and once case of bronchitis in the placebo group (Ataga 2008).

In the Phase III senicapoc study there was no significant difference in other sickle cell-related events (pneumonia, asthma, fever, catheter-related infections) between the senicapoc and the placebo groups (Ataga 2011).

In the zinc study, there were 108 episodes of infection reported in the intervention group compared to 204 in the control group (Gupta 1995).

\section{Adverse drug reactions}

In the Phase II senicapoc study three participants discontinued the study due to adverse events (Ataga 2008). One of the participants in the low-dose senicapoc group had dyspnoea and weakness and two in the high-dose senicapoc group had acute chest syndrome and painful crises. Diarrhea and nausea of mild to moderate intensity were more common in the senicapoc groups compared to the placebo group.

Nausea and urinary tract infections were significantly higher in the senicapoc-treated participants compared to placebo in the Phase III senicapoc study. All other adverse events were similar between the two treatment groups (Ataga 2011).

The Gupta study states that zinc was well-tolerated with no significant toxicity throughout the study, although it was unclear which potential toxic effects were monitored (Gupta 1995).

\section{DISCUSSION}

Zinc deficiency in sickle cell disease has been shown in observational studies to correlate with disease severity (Gupta 1987; Karayalcin 1974). Laboratory studies have shown that zinc can improve the sickle cell membrane status and antagonise intracellular calcium, and could therefore affect red blood cell dehydration (Bennekou 2001). The Gupta study included in this review showed a significant reduction in the number of sickle-related events in one and a half years of use in people treated with zinc sulphate (moderate-quality evidence) (Gupta 1995). However, lack of data in the publication makes it difficult to analyse the effect on other outcomes, on painful crisis frequency in particular (lowquality evidence). In addition, changes to hematological indices, which could be used as biomarkers of RBC sickling, were inconclusive (very low-quality evidence). Further research is required to evaluate the effect of zinc on the basic mechanisms of sickle cell disease. Previous studies using zinc also suggest a benefit for other problems in sickle cell disease, including leg ulcers (Serjeant 1970), growth (Zemel 2001), infection (Prasad 1999) and androgen deficiency in male participants (Prasad 1981). However, these studies were not included in the review since they do not consider prevention of vaso-occlusive crises.

Senicapoc (ICA-17043) is a selective and potent blocker of the Gardos channel in the RBC (Stocker 2003). The effect of this drug on the markers of hemolysis and hemoglobin level was evaluated in a 12-week, Phase II randomized double-blind study in people with sickle cell disease (Ataga 2008). The findings of this study suggested an increase in the lifespan of the sickle red blood cells (very low-quality evidence), but there was no difference in the incidence of painful crises (low-quality evidence). A subsequent Phase III study was terminated early due to the lack of improvement in the vaso-occlusive pain crisis in people with sickle cell disease (Ataga 2011).

A number of other studies did not satisfy the inclusion criteria, but are still relevant to this review. Cetiedil citrate is believed to act at the Gardos channel, antagonising the calcium-mediated potassium efflux from RBCs, thus affecting red blood cell hydration and preventing sickling. In two randomized controlled trials investigating this treatment of sickle pain crises, both found it to limit the duration of a pain crisis and reduce the number of sites of pain compared to placebo (Benjamin 1986; Cabannes 1983). No studies have tested its use in preventing sickle crises.

Piracetam improves red blood cell rheology; however, the exact mechanism of this on the red blood cell membrane is unclear. It was initially believed to inhibit the Gardos channel, but later studies disproved this theory (Stone 1988; Stuart 1992). It has been shown in one randomized controlled trial to decrease the number of pain crises (Piracetam Study 1998) and in another to have no effect in preventing pain crises (Alvim 2005). For further information, please see the relevant Cochrane Review (Al Hajeri 2007).

Magnesium is known to inhibit the potassium-chlorine ion pump, and observational studies have shown benefits in sickle cell disease.

Sodium cromoglicolate can stabilise erythrocyte membranes by blocking chlorine or calcium channels. In an ex vivo study, two groups of nine children were given sodium cromoglicolate either by the nasal route or inhalation (Toppet 2000). The percentage 
of sickled cells in the blood of all children significantly decreased, regardless of which group they were assigned to. Further studies are now needed to test the clinical benefit of this agent.

Diltiazem also proved useful in a pilot study which measured sickle pain intensity and duration and various hematological parameters (Rubio 1992). It is a calcium channel blocker and may impact on red blood cell hydration.

It was been hypothesised that hydroxyurea may increase intrinsic levels of nitric oxide, and this may affect red blood cell hydration. Effectiveness of hydroxyurea is considered in a different Cochrane Review (Jones 2001).

Zinc sulphate appears to be of benefit to people with sickle cell disease (Gupta 1995).

However, further research in the form of large well-designed randomized controlled trials is required to fully elucidate the true value in sickle cell disease of drugs which aim to prevent red blood cell dehydration.

Given this is no longer an active area of research, this review will no longer be regularly updated.

\section{AUTHORS, CONCLUSIONS}

\section{Implications for practice}

There is low-quality evidence that zinc sulphate is associated with a reduction in pain crises, and also with reductions in other sickle cell-related crises. This was despite the treatment not being associated with an improvement in any of the hematological outcomes.
While these results are encouraging, widespread introduction of this agent in the management of people with sickle cell disease is not indicated at present.

Senicapoc clearly improves the red blood cell survival in a dosedependent manner (very low-quality evidence). But the improvement in the laboratory measures did not translate into clinical benefits. There was no reduction in the incidence of sickle cell crises with the use of senicapoc (low-quality evidence). Therefore, currently this drug cannot be used in clinical practice for the prevention of vaso-occlusive crises.

\section{Implications for research}

More studies are needed to evaluate the effect of zinc sulphate and of piracetam on the basic mechanisms of sickle cell disease. Further multicenter randomized controlled trials of zinc sulphate in people with sickle cell disease should be conducted. To investigate whether the findings previously reported are consistent and sustained, these future studies should be larger and longer term than the one reported in this review. Senicapoc improved red blood cell survival and decreased hemolysis. Further studies are needed to ascertain if this drug will be beneficial in some of the other complications of sickle cell disease such as pulmonary hypertension.

\section{ACKNOWLEDGEMENTS}

We would like to acknowledge the significant contribution made on this review by the original authors - Dr Ceri Hirst and Dr Lucia de Franceschi.

\section{R E F E R E N C E S}

\section{References to studies included in this review}

Ataga 2008 \{published data only\}

Ataga KI, Smith WR, De Castro LM, Swerdlow P, Saunthararajah Y, Castro O, et al. Efficacy and safety of the Gardos channel blocker, senicapoc (ICA-17043), in patients with sickle cell anemia. Blood 2008;111(8):3991-7.

Ataga 2011 \{published data only\}

Ataga KI, Reid M, Ballas SK, Yasin Z, Bigelow C, James LS, et al. Improvements in haemolysis and indicators of erythrocyte survival do not correlate with acute vasoocclusive crises in patients with sickle cell disease: a phase III randomized, placebo-controlled, double-blind study of the Gardos channel blocker senicapoc (ICA-17043). British Journal of Haematology 2011;153(1):92-104.

Gupta 1995 \{published data only\}

Gupta VL, Chaubey BS. Efficacy of zinc therapy in prevention of crisis in sickle cell anemia: a double blind, randomized controlled clinical trial. Journal of the Association of Physicians of India 1995;43(7):467-9.

\section{References to studies excluded from this review}

Adadevoh 1973 \{published data only\} Adadevoh BK, Isaacs WA. The effect of megestrol acetate on sickling. American Journal of the Medical Sciences 1973; 265(5):367-70.

Adams-Graves 1997 \{published and unpublished data\} Adams-Graves P, Kedar A, Koshy M, Steinberg M, Veith R, Ward D. Rheothrx (Poloxamer 188) injection for the acute painful episode of sickle cell disease (SCD): a pilot study. Proceedings of the 30th Annual Meeting of the National Sickle Cell Disease Program; March 1995. 1995:118.

* Adams-Graves P, Kedar A, Koshy M, Steinberg M, Veith R, Ward D, et al. RheothRx (Poloxamer 188) injection for 
the acute painful episode of sickle cell disease: a pilot study. Blood 1997;90(5):2041-6.

Adams-Graves P, Mauer A. RheothRx ${ }^{\circledR}$ (poloxamer 188) injection for the acute painful episode of sickle cell disease. Blood 1994;84(Suppl):410a.

Emanuele M, Adams-Graves P, Kedar A, Koshy M, Steinberg R, Veith R, et al. RheothRx (Poloxamer 188) lowers serum LDH during an acute painful episode of sickle cell disease. Blood 1996;88(10 (Suppl 1)):13a.

Akinsulie 2005 \{published data only\}

Akinsulie AO, Temiye EO, Akanmu AS, Lesi FE, Whyte CO. Clinical evaluation of extract of Cajanus cajan (Ciklavit) in sickle cell anaemia. Journal of Tropical Pediatrics 2005;51(4):200-5.

Al-Jam'a 1999 \{published data only\}

Al-Jam'a AH, Al-Dabbous IA, Rafiq MS, Al-Khatti A, AlSalem AH, Al-Baharna A, et al. Isoxsuprine in the treatment of sickle cell painful crises: a double-blind comparative study with narcotic analgesia. Annals of Saudi Medicine 1999;19(2):97-100.

Alvim 2005 \{published data only\}

Alvim RC, Viana MB, Pires MA, Franklin HM, Paula MJ, Brito AC, et al. Inefficacy of piracetam in the prevention of painful crises in children and adolescents with sickle cell disease. Acta Haematologica 2005;113(4):228-33.

Ataga 2002 \{published data only\}

Ataga KI, Orringer EP, Styles L, Vichinsky E, Swerdlow P, Davis GA, et al. A phase 1B randomized, double-blind, placebo-controlled, single-dose, dose-escalation study of IC 17043 in patients with sickle cell disease (SCD). Proceedings of the 30th Annual Meeting of the National Sickle Cell Disease Program. 2002:41a.

Ataga KI, Orringer EP, Styles L, Vichinsky E, Swerdlow P, Davis GA, et al. A phase 1B randomized, double-blind, placebo-controlled, single-dose, dose-escalation study of ICA-17043 in patients with sickle cell disease (SCD). Blood 2002;100(11 (Part 1 of 2)):454a.

Ayra 1996 \{published data only\}

Arya R, Rolan PE, Wootton R, Posner J, Bellingham AJ. Tucaresol increases oxygen affinity and reduces haemolysis in subjects with sickle cell anaemia. British Journal of Haematology 1996;93(4):817-21.

Bartolucci 2009 \{published data only\} Bartolucci P, El Murr T, Roudot-Thoraval F, Habibi A, Santin A, Renaud B, et al. A randomized, controlled clinical trial of ketoprofen for sickle-cell disease vaso-occlusive crises in adults. Blood 2009; Vol. 114, issue 18:3742-7. MEDLINE: 93124810

Beatty 2007 \{published data only\}

Beatty JR, Calamaras DM, Gamerman SE, Nuuhiwa JKB, Schmidt NA. The effect of guided imagery on pain in children. Proceedings of the 35th Anniversary Convention of the National Sickle Cell Disease Program; 2007 Sep 1722; Washington DC, USA. 2007:346.
Benjamin 1986 \{published data only\}

Benjamin LJ, Berkowitz LR, Orringer E, Mankad VN, Prasad AS, Lewkow LM, et al. A collaborative, doubleblind randomized study of cetiedil citrate in sickle cell crisis. Blood 1986;67(5):1442-7.

Billet 1989 \{published data only\} Billett HH, Kaul DK, Connel MM, Fabry ME, Nagel RL. Pentoxifylline (Trental) has no significant effect on laboratory parameters in sickle cell disease. Nouvelle Revue Francaise d'Hematologie 1989;31(6):403-7.

Cabannes 1983 \{published data only\} Cabannes R, Sangare A, Cho YW. Acute painful sicklecell crises in children: a double-blind, placebo-controlled evaluation of efficacy and safety of cetiedil. Clinical Trials Journal 1983;20(4):207-18.

\section{Cabannes 1984 \{published data only\}} Cabannes R, Lonsdorfer J, Castaigne JP, Ondo A, Plassard A, Zohoun I. Clinical and biological double-blind-study of Ticlopidine in preventive treatment of sickle cell disease crises. Agents and Actions Supplements 1984;15:199-212.

\section{De Abood 1997 \{published data only\}}

De Abood M, de Castillo Z, Guerrero F, Espino M, Austin KL. Effect of Depo-Provera ${ }^{\circledR}$ or Microgynon ${ }^{\circledR}$ on the painful crises of sickle cell anemia patients. Contraception 1997;56(5):313-6.

\section{De Ceulaer 1982 \{published data only\}}

* De Ceulaer K, Gruber C, Hayes R, Serjeant GR. Medroxyprogesterone acetate and homozygous sickle cell disease. Lancet 1982;2(8292):229-31.

De Ceulaer K, Gruber C, Serjeant G. Effect of depo-provera on the haematological and clinical features of homozygous sickle cell disease. Proceedings of the Commonwealth Caribbean Medical Research Council, 27th Scientific Meeting; 1982 April 14-17; Trinidad and Tobago. 1982:47.

\section{De Ceulaer 1990 \{published data only\}} De Ceulaer K, Serjeant GR, Nagel RL, Billett HH, Christakis J, Loukopoulos D, et al. Intravenous oxypentifylline and the painful crisis of sickle cell disease. Clinical Hemorheology 1990;10(1):35-42.

Gail 1982 \{published data only\} Gail M, Beach J, Dark A, Lewis R, Morrow H. A doubleblind randomized trial of low-dose urea to prevent sickle cell crises. Journal of Chronic Diseases 1982;35(2):151-61.

\section{Gladwin 2011 \{published data only\}}

Gladwin MT, Kato GJ, Weiner D, Onyekwere OC, Dampier C, Hsu L, et al. Nitric oxide for inhalation in the acute treatment of sickle cell pain crisis: a randomized controlled trial. JAMA 2011; Vol. 305, issue 9:893-902. MEDLINE: 93124810

\section{Godeau 2003 \{published data only\}}

Godeau B, Roudet-Thoraval F, Havivi A, Elmur T, Bachir D, Paul M, et al. Assessment of ketoprofen for acute vasoocclusive crisis in adult patients with sickle cell disease. A randomized double blind monocentric study. Blood 2003; 102(11):2824a. 
Isaacs 1971 \{published data only\}

Isaacs WA. The effect of certain lipid substances on sickling. Acta Haematologica 1971;45(4):259-65.

Isaacs WA, Effiong CE, Ayeni O. Steroid treatment in the prevention of painful episodes in sickle-cell disease. Lancet 1972;1(7750):570-1.

Jacobson 1997 \{published and unpublished data\} * Jacobson SJ, Kopecky EA, Joshi P, Babul N. Randomised trial of oral morphine for painful episodes of sickle-cell disease in children. Lancet 1997;350(9088):1358-61. Kopesky EA, Jacobson S, Joshi P, Koren G. Systemic exposure to morphine and the risk of acute chest syndrome in sickle cell disease. Clinical Pharmacology and Therapeutics 2004;75(3):140-6.

Lonsdorfer 1984 \{published data only\}

Lonsdorfer J, Castaigne JP, Lenormand E, Otayeck A, Bogui P, Dosso Y, et al. Beneficial effects of Ticlopidine on cardiopulmonary function of sickle cell patients not in crisis. Agents and Actions Supplements 1984;15:213-8.

Mahmood 1969 \{published data only\}

Mahmood A. A double-blind trial of a phenothiazine compound in the treatment of clinical crisis of sickle cell anaemia. British Journal of Haematology 1969;16(1):181-4.

Manion 2001 \{published data only\}

Manion C, Parkhurst JB, Ogle B, Johnson A, Edmundson A. Aspartame inhibits hypoxia-induced sickling of erythrocytes in patients with sickle cell disease. Proceedings of the 24th Annual Meeting of the National Sickle Cell Disease Program. 2000:172a.

* Manion CV, Howard J, Ogle B, Parkhurst J, Edmundson A. Aspartame effect in sickle cell anemia. Clinical Pharmacology and Therapeutics 2001;69(5):346-55.

Manrique 1987 \{published data only\} Manrique RV. Placebo controlled double-blind study of pentoxifylline in sickle cell disease patients. Journal of Medicine 1987;18(5\&6):277-91.

Orringer 1991 \{published data only\}

Orringer E, Huffman J, Johnson A, Jones S, Whitney J, Brockenbrough S, et al. A clinical study of the safety, pharmacokinetics and pharmacodynamics of intravenous infusions of $12 \mathrm{C} 79$ in sickle cell disease patients not in crisis. Proceedings of the 16th Annual Meeting of the National Sickle Cell Disease Program; March 1991. 1991:112. Orringer EP, Binder EA, Thomas RP, Blythe DS, Bustrack JA, Schroeder DH, et al. Phase 1 study of BW 12C in sickle cell disease (SCD) patients not in crisis. Blood 1988;5 (Suppl 1):69a.

Orringer EP, Binder EA, Thomas RP, Blythe DS, Bustrack JA, Schroeder DH, et al. Phase I study of $12 \mathrm{C} 79$ in sickle cell disease (SCD) patients not in crisis. Proceedings of the 14th Annual Meeting of the National Sickle Cell Disease Program. 1989:57.

Osamo 1981 \{published data only\}

Osamo NO, Photiades DP, Famodu AA. Therapeutic effect of aspirin in sickle cell anaemia. Acta Haematologica 1981; 66(2):102-7.
Oski 1968 \{published data only\}

Oski F, Call FL, Lessen L. Failure of promazine $\mathrm{HCl}$ to prevent the painful episodes in sickle cell anemia. Journal of Pediatrics 1968;73(2):265-6.

\section{Oyewo 1987 \{published data only\}}

Oyewo EA. Therapeutic effect of diflusinal as prophylaxis in sickle cell anaemia. Clinical Trials Journal 1987;24(3): 249-53.

\section{Pace 2003 \{published data only\}}

Pace BS, Shartava A, Pack-Mabien A, Mulekar M, Ardia A, Goodman SR. Effects of N-acetylcysteine on dense cell formation in sickle cell disease. American Journal of Hematology 2003;73(1):26-32.

Pichard 1987 \{published data only\} Pichard E, Duflo B, Coulibaly S, Mariko B, Monsempes JL, Traore HA, et al. Effectiveness of treatment during osteoarticular pain crises in drepanocytosis; based on the example of pentoxifylline [Evaluation de L'efficacite des traitements au cours des crises douloureuses osteo-articulaires de la drepanocytose exemple de la pentoxifylline]. Bulletin de la Societe de Pathologie Exotique et de ses Filiales (Paris) 1987;80(5):834-40.

Piracetam Study 1998 \{published data only\} El-Hazmi AF, Warsy AS, Al-Fawaz I, Farid M, Refai S, Opawoye AD, et al. Piracetam in the treatment of sickle cell disease. Proceedings of the 20th Annual Meeting of the National Sickle Cell Disease Program. 1995:162a. El-Hazmi MAF, Warsy AS, Al-Fawaz I, Opawoye AD, Abu Taleb H, Howsawi Z, et al. Piracetam is useful in the treatment of children with sickle cell disease. Acta Haematologica 1996;96(4):221-6.

* The Piracetam Study Group. Piracetam for the treatment of sickle cell disease in children - a double blind test. Saudi Medical Journal 1998;19(1):22-7.

Poflee 1991 \{published data only\} Poflee VW, Gupta OP, Jain AP, Jajoo UN. Haemorheological treatment of painful sickle cell crises: use of pentoxifylline. Journal of the Association of Physicians India 1991;39(8): 608-9.

Qari 2007 \{published data only\} Qari MH, Aljaouni SK, Alardawi MS, Fatani H, Alsayes FM, Zografos P, et al. Reduction of painful vaso-occlusive crisis of sickle cell anaemia by tinzaparin in a double-blind randomized trial. Thrombosis and Haemostasis 2007;98(2): 392-6.

Rubio 1992 \{published data only\} Rubio A, Cox C, Weintraub M. Prediction of diltiazem plasma concentration curves from limited measurements using compliance data. Clinical Pharmacokinetics 1992;22 (3):238-46.

Rubio A, Weintraub M. Scoring system in a pilot effectiveness study of patients with sickle cell anemia. Journal of Clinical Research and Pharmacoepidemiology 1992; 6:47-54. 
Semple 1984 \{published data only\}

Semple MJ, Al-Hasani SF, Kioy P, Savidge GF. A doubleblind trial of Ticlopidine in sickle cell disease. Thrombosis and Haemostasis 1984;51(3):303-6.

Silva-Pinto 2007 \{published data only\} Silva-Pinto AC, Carrara RC, Oliveira VC, Palma PV, Campos AD, Zago MA, Covas DT. Hydroxyurea treatment of sickle cell diseases causes megaloblastic transformation of the bone marrow that is responsible for the increase of the mean corpuscular volume. Haematologica 2007;92(Suppl 1):298.

Teuscher 1988 \{published data only\} Teuscher T, Weil Von Der Ahe C, Baillod P, Holzer B. Double blind randomised clinical trial of pentoxiphyllin in vaso-occlusive sickle cell crisis. Tropical and Geographical Medicine 1989;41(4):320-5.

Toppet 2000 \{published data only\}

Toppet M, Fall ABK, Ferster A, Fondu P, Melot C, Vanhaelen-Fastre R, et al. Antisickling activity of sodium cromoglicate in sickle-cell disease [letter]. Lancet 2000;356 (9226):309.

Urea Trial 1974 \{published data only\} Cooperative Urea Trials Group. Clinical trials of therapy for sickle cell vaso-occlusive crises. Journal of the American Medical Association 1974;228(9):1120-4.

Urea Trial 21974 \{published data only\}

Cooperative Urea Trials Group. Treatment of sickle cell crisis with urea in invert sugar. A controlled trial. JAMA 1974;228(9):1125-8.

Urea Trial 31974 \{published data only\} Cooperative Urea Trials Group. Controlled clinical trials and cooperative study of intravenously administered alkali. JAMA 1974;228(9):1129-31.

Uzun 2010 \{published data only\}

Uzun B, Kekec Z, Gurkan E. Efficacy of tramadol vs meperidine in vasoocclusive sickle cell crisis. American Journal of Emergency Medicine 2010; Vol. 28, issue 4: 445-9. MEDLINE: 93124810

Wallen 2007 \{published data only\}

Wallen GR, Handel D, Mendoza J, Chestnut W, Nichols J, Yates J, et al. A randomized pilot study exploring hypnosis as a pain and symptom management strategy in patients with sickle cell disease. 35th Anniversary Convention of the National Sickle Cell Disease Program; 2007 Sep 17-22; Washington DC, USA.. 2007:261.

\section{Wambebe 2001 \{published data only\}}

Fonnebo V. Indigenous Nigerian medicinal plants may be useful in the management of sickle-cell disorder. Focus on Alternative and Complementary Therapies 2002;7(2):146. Wambebe C. Chemistry and clinical evaluation of NIPRISAN in patients with sickle cell anemia. Proceedings of the 30th Annual Meeting of the National Sickle Cell Disease Program. 2002:46a.

* Wambebe C, Khamofu H, Momoh JAF, Ekpeyong M, Audu BS, Njoku OS, et al. Double-blind, placebocontrolled, randomised cross-over clinical trial of Niprisan in patients with sickle cell disorder. Phytomedicine 2001;8 (4):252-61.

Wambebe CO, Bamgboye EA, Badru BO, Khamofu H, Momoh JA, Ekpeyong M, et al. Efficacy of niprisan in the prophylactic management of patients with sickle cell disease. Current Therapeutic Research, Clinical and Experimental 2001;62(1):26-34.

Weiner 2002 \{published data only\}

Weiner DL, Hibberd PL, Betit P, Botelho CA, Cooper AB, Brugnara C. Inhaled nitric oxide for treatment of acute vaso-occlusive crisis in sickle cell disease. Blood 2002;100 (11 Pt 1):11a.

Weiner DL, Hibberd PL, Betit P, Brugnara C. Effectiveness and safety of inhaled nitric oxide for the treatment of vasoocclusive crisis in pediatric sickle cell disease. Pediatric Research 2002;51(4 Suppl):86A.

* Weiner DL, Hibberd PL, Betit P, Cooper AB, Botelho $\mathrm{CA}$, Brugnara C. Preliminary assessment of inhaled nitric oxide for acute vaso-occlusive crisis in pediatric patients with sickle cell disease. JAMA 2003;289(9):1136-42.

\section{Wynn 2007 \{published data only\}}

Wynn L, Debenham E, Faughnan L, Martin B, Kelly T, Reed C, et al. Recruitment in the baby hug pediatric hydroxyurea phase 3 clinical trial. 35th Anniversary Convention of the National Sickle Cell Disease Program; 2007 Sep 17-22; Washington DC, USA. 2007:245.

\section{Zago 1984 \{published data only\}}

Zago MA, Costa FF, Ismael SJ, Tone LG, Bottura C. Treatment of sickle cell diseases with aspirin. Acta Haematologica 1984;72(1):61-4.

\section{Additional references}

\section{Adrie 2000}

Adrie C, Kister J, De Franceschi L, Rouyer-Fessard P, Kieger L, Marden M, et al. Nitric oxide restores the erythrocyte density of the SAD mouse model of sickle cell disease. Blood 2000;96(11):Parts 1 and 2.

\section{Al Hajeri 2007}

Al Hajeri AA, Fedorowicz Z, Omran A, Tadmouri GO. Piracetam for reducing the incidence of painful sickle cell disease crises. Cochrane Database of Systematic Reviews 2007, Issue 2. DOI: 10.1002/14651858.CD006111.pub2

\section{Ballas 1989}

Ballas SK, Dover GJ, Charache S. Effect of hydroxyurea on the rheological properties of sickle erythrocytes in vivo. American Journal of Hematology 1989;32(2):104-11.

\section{Ballas 2000}

Ballas SK. Hydration of sickle erythrocytes using a naturally occurring sodium ionophore. Blood 2000;96(11):Parts 1 and 2.

\section{Bennekou 2000}

Bennekou P, Pederson O, Moller A, Christopherses P. Volume control in sickle cells is facilitated by novel anion conductance inhibitor NS1652. Blood 2000;95(5):1842-8. 
Bennekou 2001

Bennekou P, de Franceschi L, Pedersen O, Lian L, Asakura T, Evans G, et al. Treatment with NS3623, a novel Clconductance blocker, amiliorates erythrocyte dehydration in transgenic SAD mice: a possible new therapeutic approach for sickle cell disease. Blood 2001;97(5):1451-7.

\section{Brugnara 1987}

Brugnara C, Tosteson DC. Inhibition of K transport by divalent cations in sickle erythrocytes. Blood 1987;70(6): 1810-5.

Brugnara 1993

Brugnara C, De Franceschi L, Alper SL. Inhibition of $\mathrm{Ca} 2$ +activated $\mathrm{K}+$ transport and cell dehydration in sickle erythrocytes by clotrimazole and other imidazole derivatives. Journal of Clinical Investigation 1993;92(1):520-6.

\section{Brugnara 1995}

Brugnara C. Red cell dehydration in pathophysiology and treatment of sickle cell disease. Current Opinion in Hematology 1995;2(2):132-8.

\section{Brugnara 1996}

Brugnara C, Gee B, Armsby CC, Kurth S, Sakamoto M, Rifai N, et al. Therapy with oral clotrimazole induces inhibition of the Gardos channel and reduction of erythrocyte dehydration in patients with sickle cell disease. Journal of Clinical Investigation 1996;97(5):1227-34.

\section{Charache 1995}

Charache S, Terrin M, Moore R, Dover G, Barton F, Eckert $S$, et al. Effect of hydroxyurea on the frequency of painful crises in sickle cell anemia. New England Journal of Medicine 1995;332(20):1317-22.

\section{Davies 1997}

Davies SC, Oni L. Management of patients with sickle cell disease. BMJ 1997;315(7109):656-60.

\section{de Franceschi 1994}

de Franceschi L, Saadane N, Trudel M, Alper S L, Brugnara C, Beuzard Y. Treatment with oral clotrimazole blocks $\mathrm{Ca}(2+)$-activated $\mathrm{K}+$ transport and reverses erythrocyte dehydration in transgenic SAD mice. A model for therapy of sickle cell disease.. Journal of Clinical Investigation 1994; 93(4):1670-6.

\section{Elbourne 2002}

Elbourne DR, Altman DG, Higgins JPT, Curtin F, Worthington HV, Vail A. Meta-analyses involving crossover trials: methodological issues. International Journal of Epidemiology 2002;31(1):140-9.

\section{Gibson 1998}

Gibson X A, Shartava A, McIntyre J, Monteiro C A, Zhang Y, Shah A, et al. The efficacy of reducing agents or antioxidants in blocking the formation of dense cells and irreversibly sickled cells in vitro. Blood 1998;91(11): 4373-8.

\section{Gibson 2000}

Gibson JS, Stewart GW, Ellory JC. Effect of dimethyl adipimidate on $\mathrm{K}+$ transport and shape change in red blood cells from sickle cell patients. FEBS Letters 2000;480(2-3): 179-83.

Gini 1987

Gini EK, Sonnet J. Use of piracetam improves sickle cell deformability in vitro and in vivo. Journal of Clinical Pathology 1987;40(1):99-102.

\section{Gupta 1987}

Gupta VL, Chaubey BS. Red blood cell survival, zinc deficiency and efficacy of zinc therapy in sickle cell disease. In: Fucharoen S, Rowley PT, Paul NW editor(s). Thalassemia: pathophysiology and management, part A. Vol. 23, New York: Alan R Liss Inc, 1987:477-83.

Hankins 2008

Hankins JS, Wynn LW, Brugnara C, Hillery CA, Li CS, Wang WC. Phase I study of magnesium pidolate in combination with hydroxycarbamide for children with sickle cell anaemia. British Journal of Haematology 2008;140 (1):80-5.

\section{Hickman 1999}

Hickman M, Modell B, Greengross P, Chapman C, Layton M, Falconer S, et al. Mapping the prevalence of sickle cell disease and beta thalassaemia in England: estimating and validating ethnic-specific rates. British Journal of Haematology 1999;104(4):860-7.

\section{Higgins 2003}

Higgins JPT, Thompson SG, Deeks JJ, Altman DG. Measuring inconsistency in meta-analyses. BMJ 2003;327 (7414):557-600.

\section{Jones 2001}

Jones AP, Davies SC, Olujohungbe A. Hydroxyurea for sickle cell disease. Cochrane Database of Systematic Reviews 2001, Issue 2. DOI: 10.1002/14651858.CD002202

\section{Karayalcin 1974}

Karayalcin G, Rosner F, Kim KY, Chandra P. Plasma-zinc in sickle cell-anaemia [letter]. Lancet 1974;1(7850):217.

\section{Leikin 1989}

Leikin SL, Gallagher D, Kinney TR, Sloane D, Klug P, Rida W. Mortality in children and adolescents with sickle cell disease. Pediatrics 1989;84(3):500-8.

\section{Prasad 1981}

Prasad AS, Abbasi AA, Rabbani P, DuMouchelle E. Effect of zinc supplementation on serum testosterone level in adult male sickle cell anemia subjects. American Journal of Hematology 1981;10(2):119-27.

\section{Prasad 1999}

Prasad AS, Beck FWJ, Kaplan J, Chandrasekar PH, Ortega J, Fitzgerald JT, et al. Effect of zinc supplementation on incidence of infections and hospital admissions in sickle cell disease (SCD). American Journal of Hematology 1999;61(3): 194-202.

\section{Qureshi 2000}

Qureshi MA, Gugnani MK, Swerdlow PS, Girgis RE. Decreased exhaled nitric oxide (NO) in patients with sickle cell disease. Blood 2000;96(11 (Pt 1 and 2)). 


\section{Rivera 2000}

Rivera A, Brugnara C. Vaso-active molecules modulate Gardos channel activity and hydration state of normal and sickle erythrocytes. Blood. 2000; Vol. 96, issue 11 (Pt 1 and 2).

\section{Romero 2000}

Romero JR, Suzuka SM, Nagel RL, Fabry ME. Arginine supplementation of sickle transgenic mice: effects on red cell density and potassium transport. Blood 2000;96(11 (Pt 1 and 2)).

\section{Romero 2002}

Romero JR, Suzuka SM, Nagel RL, Fabry ME. Arginine supplementation of sickle transgenic mice reduces red cell density and Gardos channel activity. Blood 2002;99(4): $1103-8$.

\section{Serjeant 1970}

Serjeant GR, Galloway RE, Gueri MC. Oral zinc sulphate in sickle-cell ulcers. Lancet 1970;2(7679):891-2.

\section{Serjeant 1992}

Serjeant GR. Sickle cell disease. 2nd Edition. New York: Oxford Medical Publications, 1992.

\section{Stocker 2000}

Stocker J, De Franceschi L, McNaughton-Smith G, Brugnara C. A novel Gardos channel inhibitor, ICA-17043, prevents red blood cell dehydration in vitro and in a mouse model (SAD) of sickle cell disease. Blood 2000;96(11 (Pt 1 and 2)).

\section{Stocker 2003}

Stocker JW, De Franceschi L, McNaughton-Smith GA, Corrocher R, Beuzard Y, Brugnara C. ICA-17043, a novel Gardos channel blocker, prevents sickled red blood cell dehydration in vitro and in vivo in SAD mice. Blood 2003; 101(6):2412-8.

\section{Stone 1988}

Stone PCW, Chalder SM, Stuart J. Action of piracetam on cation flux and deformability of sickle cells. Clinical Hemorheology 1988;8(5):779-90.

\section{Stuart 1990}

Stuart J, Stone PCW, Nash GB, Ellory JC. Effect of Piracetam on Ca2+-induced $\mathrm{K}+$ efflux from sickle cells Clinical Hemorheology 1990;10(5):535-40.

\section{Stuart 1992}

Stuart J. Rheological consequences of sickle-cell dehydration. Clinical Hemorheology 1992;12(2):203-16.

\section{Zemel 2001}

Zemel B, Kawchak D, Fung E, Ohene-Frempong K, Stallings V. Zinc supplementation and linear growth in children with sickle cell disease: a pilot study. Proceedings of the 25th Annual Meting of the National Sickle Cell Disease Program; April 2001; New York. 2001:Abst \#232.

\section{References to other published versions of this review}

\section{Nagalla 2010}

Nagalla S, Ballas SK. Drugs for preventing red blood cell dehydration in people with sickle cell disease. Cochrane Database of Systematic Reviews 2010, Issue 1. DOI: 10.1002/14651858.CD003426.pub3

\section{Nagalla 2012}

Nagalla S, Ballas SK. Drugs for preventing red blood cell dehydration in people with sickle cell disease. Cochrane Database of Systematic Reviews 2012, Issue 7. DOI: 10.1002/14651858.CD003426.pub4

\section{Riddington 2002}

Riddington C, De Franceschi L. Drugs for preventing red blood cell dehydration in people with sickle cell disease. Cochrane Database of Systematic Reviews 2002, Issue 4. DOI: 10.1002/14651858.CD003426.pub2

\section{Singh 2007}

Singh PC, Ballas SK. Drugs for preventing red blood cell dehydration in people with sickle cell disease. Cochrane Database of Systematic Reviews 2007, Issue 4. DOI: 10.1002/14651858.CD003426.pub2

* Indicates the major publication for the study 


\title{
CHARACTERISTICS OF STUDIES
}

\section{Characteristics of included studies [ordered by study ID]}

\author{
Ataga 2008
}

Methods

Phase II, randomized, double-blind, placebo-controlled study. There was a screening phase and a 12-week treatment phase

Participants

90 sickle cell participants were recruited at 19 medical centers in the USA. The participants were adults aged between 18 and 60 years with at least one episode of sickle cellrelated painful crisis 4 weeks prior to the study screening

Interventions
$\begin{aligned} & \text { Participants were randomized to either: } \\ & \text { 1. high-dose senicapoc: a single } 150 \mathrm{mg} \text { senicapoc loading dose followed by } 10 \mathrm{mg} \text { daily } \\ & \text { maintenance dose; } \\ & \text { 2. low-dose senicapoc: a single } 100 \mathrm{mg} \text { senicapoc loading dose followed by } 6 \mathrm{mg} \text { daily } \\ & \text { maintenance dose; or } \\ & \text { 3. placebo. }\end{aligned}$

Outcomes

Efficacy, safety, pharmacokinetic, and pharmacodynamic measures were obtained on day 1 of study, end of week 1 and every 2 weeks until the end of treatment phase

Notes

Risk of bias

\begin{tabular}{|c|c|c|}
\hline Bias & Authors' judgement & Support for judgement \\
\hline $\begin{array}{l}\text { Random sequence generation (selection } \\
\text { bias) }\end{array}$ & Low risk & $\begin{array}{l}\text { Centralized randomization protocol using } \\
\text { an integrated voice response system }\end{array}$ \\
\hline Allocation concealment (selection bias) & Unclear risk & Allocation concealment was not reported. \\
\hline $\begin{array}{l}\text { Blinding (performance bias and detection } \\
\text { bias) } \\
\text { Participants }\end{array}$ & Low risk & The participants were blinded. \\
\hline
\end{tabular}

Blinding (performance bias and detection Low risk bias)

The treating physicians were blinded.

Clinicians

Blinding (performance bias and detection Low risk The review committee was blinded. bias)

Outcome assessors

Incomplete outcome data (attrition bias) Low risk All outcomes
Modified intent to treat population was used for analysis. Two participants dropped out prior to the first efficacy analysis. A total of ten participants did not complete the 
study; full reasons for this were given in the published paper

\begin{tabular}{|c|c|c|}
\hline Selective reporting (reporting bias) & Low risk & $\begin{array}{l}\text { All outcomes stated in 'Methods' section } \\
\text { reported in 'Results' }\end{array}$ \\
\hline
\end{tabular}
reported in 'Results'

\begin{tabular}{ll} 
Other bias $\quad$ Low risk \\
\hline
\end{tabular}

No significant differences in the baseline characteristics of the study participants

\section{Ataga 2011}

Methods

Phase III randomized, double-blind, placebo-controlled, parallel group study. There was a screening phase, a 52-week treatment phase, and a follow-up evaluation 8 weeks after the end of the study

Participants

297 participants were recruited from 75 centers in the USA, Jamaica, Brazil, France, Trinidad and the UK. Participants aged between 16 and 65 years and had at least 2 episodes of painful crisis within the preceding 12 months that required medical attention were included. Participants on hydroxyurea in preceding 12 months were required to be on a stable dose of the drug prior to inclusion in the study

Interventions
$\begin{aligned} & \text { Participants were randomized to receive (in a 1:1 fashion): } \\ & \text { 1. senicapoc (loading dose of } 20 \mathrm{mg} \text { twice daily for } 4 \text { days followed by } 10 \mathrm{mg} \text { daily); or } \\ & \text { 2. placebo }\end{aligned}$

Outcomes

The primary end point was the frequency of sickle cell pain crises. TIme to the first second and third acute painful crises was a secondary end point of the study (Ataga 2011) . The effect of the drug on markers of hemolysis, hemoglobin, hematocrit, reticulocyte count, red blood cell count and dense erythrocytes was also measured. Quality of life measures were also included

Notes

\section{Risk of bias}

\begin{tabular}{l|l|l}
\hline Bias & Authors' judgement & Support for judgement \\
\hline $\begin{array}{l}\text { Random sequence generation (selection } \\
\text { bias) }\end{array}$ & Low risk & $\begin{array}{l}\text { Centralized randomization protocol using } \\
\text { an integrated voice response system }\end{array}$ \\
\hline $\begin{array}{l}\text { Allocation concealment (selection bias) } \\
\text { Blinding (performance bias and detection } \\
\text { bias) } \\
\text { Participants }\end{array}$ & Low risk & Allocation concealment was not reported. \\
\hline
\end{tabular}




\begin{tabular}{|c|c|c|}
\hline $\begin{array}{l}\text { Blinding (performance bias and detection } \\
\text { bias) } \\
\text { Clinicians }\end{array}$ & Low risk & The treating physicians were blinded. \\
\hline $\begin{array}{l}\text { Blinding (performance bias and detection } \\
\text { bias) } \\
\text { Outcome assessors }\end{array}$ & Low risk & The review committee was blinded. \\
\hline $\begin{array}{l}\text { Incomplete outcome data (attrition bias) } \\
\text { All outcomes }\end{array}$ & Low risk & $\begin{array}{l}\text { Modified intent to treat population was } \\
\text { used for analysis. The study had to be ter- } \\
\text { minated prematurely because it was un- } \\
\text { likely to meet the primary end point }\end{array}$ \\
\hline Selective reporting (reporting bias) & Low risk & $\begin{array}{l}\text { All outcomes stated in 'Methods' section } \\
\text { reported in 'Results' }\end{array}$ \\
\hline Other bias & Low risk & $\begin{array}{l}\text { No significant differences in the baseline } \\
\text { characteristics of the study participants }\end{array}$ \\
\hline
\end{tabular}

\section{Gupta 1995}

\begin{tabular}{|c|c|c|}
\hline Methods & \multicolumn{2}{|c|}{ Double-blind, placebo-controlled, randomized controlled trial } \\
\hline Participants & \multicolumn{2}{|c|}{$\begin{array}{l}145 \text { participants from India with SS disease, aged over } 5 \text { years. } 15 \text { participants were lost } \\
\text { to follow up }\end{array}$} \\
\hline Interventions & \multicolumn{2}{|c|}{$\begin{array}{l}\text { Zinc (oral } 220 \mathrm{mg} \text { tds) or placebo (identical in appearance). Participants were seen weekly, } \\
\text { follow up was for } 1.5 \text { years and the data were analysed at the end of the follow-up period }\end{array}$} \\
\hline Outcomes & \multicolumn{2}{|c|}{$\begin{array}{l}\text { Sickle related crises: vaso-occlusive; mixed; hemolytic; sequestration; and aplastic. Days } \\
\text { in hospital and working days lost }\end{array}$} \\
\hline \multicolumn{3}{|l|}{ Notes } \\
\hline \multicolumn{3}{|l|}{ Risk of bias } \\
\hline Bias & Authors' judgement & Support for judgement \\
\hline $\begin{array}{l}\text { Random sequence generation (selection } \\
\text { bias) }\end{array}$ & Low risk & $\begin{array}{l}\text { New Castle software was used to generate } \\
\text { randomization. }\end{array}$ \\
\hline Allocation concealment (selection bias) & Unclear risk & Allocation concealment was not reported. \\
\hline $\begin{array}{l}\text { Blinding (performance bias and detection } \\
\text { bias) } \\
\text { Participants }\end{array}$ & Low risk & The participants were blinded. \\
\hline
\end{tabular}




\begin{tabular}{|c|c|c|}
\hline $\begin{array}{l}\text { Blinding (performance bias and detection } \\
\text { bias) } \\
\text { Clinicians }\end{array}$ & Low risk & The treating physicians were blinded. \\
\hline $\begin{array}{l}\text { Blinding (performance bias and detection } \\
\text { bias) } \\
\text { Outcome assessors }\end{array}$ & Unclear risk & Not discussed. \\
\hline $\begin{array}{l}\text { Incomplete outcome data (attrition bias) } \\
\text { All outcomes }\end{array}$ & Unclear risk & $\begin{array}{l}\text { Fifteen, of the } 145 \text { participants recruited, } \\
\text { dropped out or were lost to follow up, and } \\
\text { these are not accounted for in the study } \\
\text { publication }\end{array}$ \\
\hline Selective reporting (reporting bias) & Low risk & $\begin{array}{l}\text { All outcomes stated in 'Methods' section } \\
\text { reported in 'Results' }\end{array}$ \\
\hline Other bias & Unclear risk & $\begin{array}{l}\text { Little information was given regarding } \\
\text { baseline characteristics, including disease } \\
\text { severity and medical history of participants, } \\
\text { making it difficult to ascertain if the groups } \\
\text { were sufficiently similar at the start of the } \\
\text { study }\end{array}$ \\
\hline
\end{tabular}

IV: intravenous

SCD: sickle cell disease

SS: sickle cell anemia

tds: three times daily

Characteristics of excluded studies [ordered by study ID]

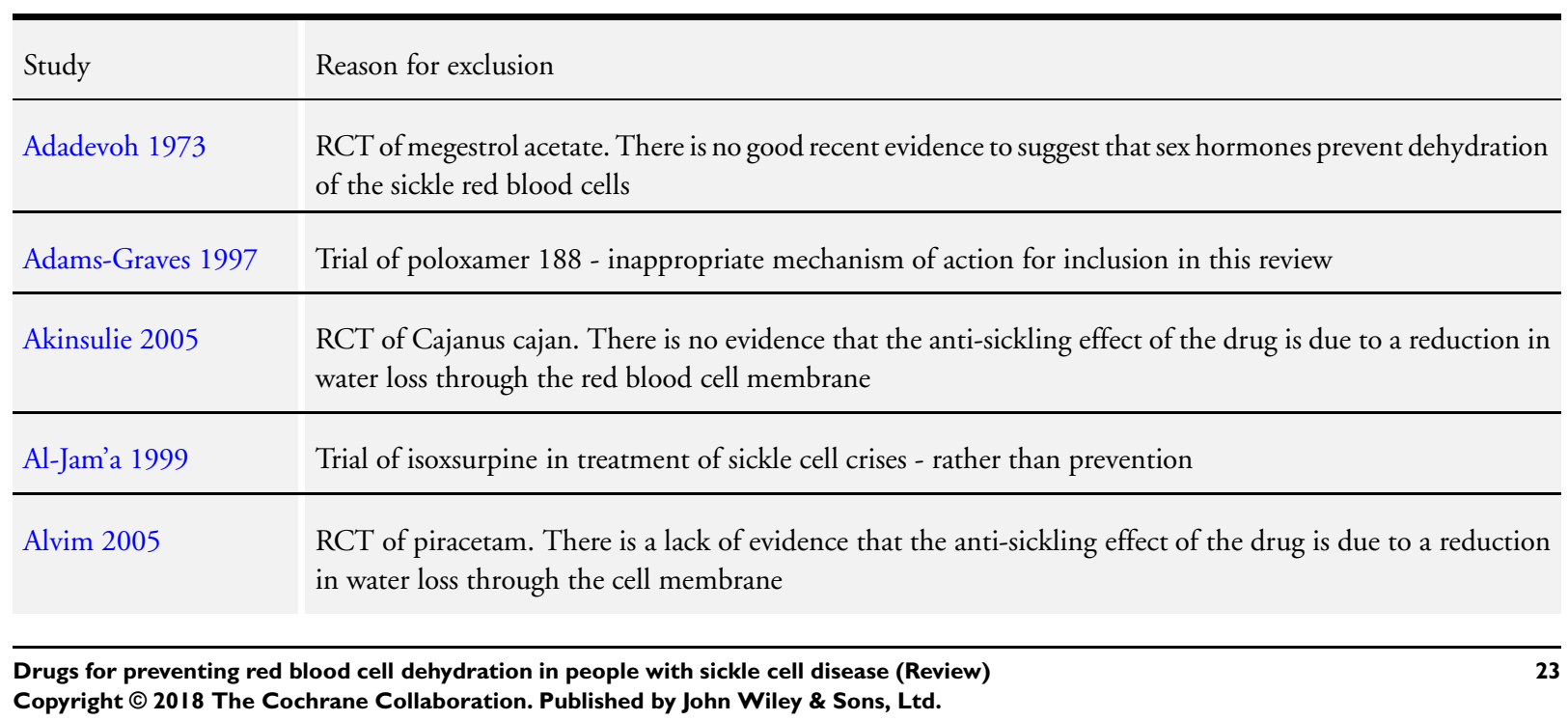


(Continued)

\begin{tabular}{|c|c|}
\hline Ataga 2002 & Pharmacokinetic study of ICA 17043 , with no measure of clinical outcomes of interest \\
\hline Ayra 1996 & RCT of tucaresol. Prevents sickling by shifting the oxygen affinity, not through red blood cell dehydration \\
\hline Bartolucci 2009 & $\begin{array}{l}\text { RCT of ketoprofen for treatment of, rather than prevention of, vaso-occlusive crises. Not a study of a drug } \\
\text { involved in the prevention of red blood cell dehydration }\end{array}$ \\
\hline Beatty 2007 & Not a study of a drug involved in the prevention of red blood cell dehydration and vaso-occlusive crisis \\
\hline Benjamin 1986 & RCT of cetiedil citrate. Used in treatment rather than prevention of crises \\
\hline Billet 1989 & $\begin{array}{l}\text { RCT of pentoxifylline. There is no evidence that the anti-sickling effect of the drug is due to a reduction in } \\
\text { water loss through the red blood cell membrane }\end{array}$ \\
\hline Cabannes 1983 & RCT of cetiedil citrate. Used in treatment rather than prevention of crises \\
\hline Cabannes 1984 & RCT of ticlopidine. Mainly an inhibitor of platelet action, rather than anti-dehydration \\
\hline De Abood 1997 & $\begin{array}{l}\text { RCT of Depo-Provera and Microgynon. There is no good evidence to suggest that sex hormones prevent } \\
\text { dehydration of the sickle red blood cells }\end{array}$ \\
\hline De Ceulaer 1982 & $\begin{array}{l}\text { RCT of medroxyprogesterone acetate. There is no good recent evidence to suggest that sex hormones prevent } \\
\text { dehydration of the sickle blood red blood cells }\end{array}$ \\
\hline De Ceulaer 1990 & $\begin{array}{l}\text { RCT of pentoxifylline. There is no evidence that the anti-sickling effect of the drug is due to a reduction in } \\
\text { water loss through the red blood cell membrane }\end{array}$ \\
\hline Gail 1982 & $\begin{array}{l}\text { RCT of urea. There is no evidence that any anti-sickling action is due to a reduction in dehydration of the } \\
\text { sickle red blood cells }\end{array}$ \\
\hline Gladwin 2011 & Not a study of a drug involved in the prevention of red blood cell dehydration \\
\hline Godeau 2003 & RCT of ketoprofen for treatment, rather than prevention, of vaso-occlusive crises \\
\hline Isaacs 1971 & $\begin{array}{l}\text { RCT of steroids. There is no good recent evidence to suggest that sex hormones prevent dehydration of the } \\
\text { sickle red blood cells }\end{array}$ \\
\hline Jacobson 1997 & $\begin{array}{l}\text { Risk analysis using data from a previous RCT, in which morphine was administered in treatment, rather } \\
\text { than prevention, of acute chest syndrome }\end{array}$ \\
\hline Lonsdorfer 1984 & RCT of ticlopidine. Mainly an inhibitor of platelet action, rather than anti-dehydration \\
\hline Mahmood 1969 & RCT of a phenothiazine. Used in treatment rather than prevention of crises \\
\hline
\end{tabular}

Manion 2001

Pharmacokinetic study of aspartame, with no measure of outcomes of interest

Drugs for preventing red blood cell dehydration in people with sickle cell disease (Review) 
(Continued)

\begin{tabular}{ll}
\hline Manrique 1987 & $\begin{array}{l}\text { RCT of pentoxifylline. There is no evidence that the anti-sickling effect of the drug is due to a reduction in } \\
\text { water loss through the red blood cell membrane }\end{array}$ \\
\hline Orringer 1991 & $\begin{array}{l}\text { RCT of } 12 \mathrm{C} 79, \text { which prevents sickling primarily by increasing oxygen affinity, with possible secondary } \\
\text { effects on the potassium-chloride co-transport channels in the red blood cell membrane }\end{array}$ \\
\hline Osamo 1981 & $\begin{array}{l}\text { Trial of aspirin. There is no evidence that any anti-sickling action is due to a reduction in dehydration of } \\
\text { the sickle red blood cells }\end{array}$ \\
\hline Oski 1968 & Study not randomized, looks at promazine chloride. \\
\hline Oyewo 1987 & $\begin{array}{l}\text { Study of diflusinal, anti-sickling effects not due to red blood cell dehydration } \\
\text { Phase II RCT of N-Acetylcysteine for prevention of sickle cell related vaso-occlusion and formation of dense } \\
\text { study in the review }\end{array}$ \\
\hline Pace 2003 &
\end{tabular}

Pichard 1987 RCT of pentoxifylline. There is no evidence that the anti-sickling effect of the drug is due to a reduction in water loss through the cell membrane

Piracetam Study 1998 RCT of piracetam. There is a lack of evidence that the anti-sickling effect of the drug is due to a reduction in water loss through the cell membrane

Poflee 1991 RCT of pentoxifylline. There is no evidence that the anti-sickling effect of the drug is due to a reduction in water loss through the cell membrane

Qari 2007 RCT of tinzaparin. There is no evidence that the anti-sickling effect of the drug is due to a reduction in water loss through the red blood cell membrane

Rubio $1992 \quad$ Pharmacokinetic study of diltiazem, with no measure of outcomes of interest

\begin{tabular}{l|l}
\hline Semple 1984 & RCT of ticlopidine. Mainly an inhibitor of platelet action, rather than anti-dehydration \\
\hline Silva-Pinto 2007 & Study of hydroxyurea, no measure of clinical outcomes of interest \\
\hline
\end{tabular}

Teuscher 1988 RCT of pentoxifylline. There is no evidence that the anti-sickling effect of the drug is due to a reduction in water loss through the cell membrane

Toppet $2000 \quad$ Non-randomized ex-vivo study of sodium cromoglicate, an anti-sickling agent, majority of patients also taking hydroxyurea

Urea Trial 1974 RCT of urea. There is no evidence that any anti-sickling action is due to a reduction in dehydration of the sickle red blood cells

Urea Trial 21974 RCT of urea. There is no evidence that any anti-sickling action is due to a reduction in dehydration of the sickle red blood cells

Drugs for preventing red blood cell dehydration in people with sickle cell disease (Review) 
(Continued)

Urea Trial 31974 RCT of urea. There is no evidence that any anti-sickling action is due to a reduction in dehydration of the sickle red blood cells

Uzun $2010 \quad$ Study of tramadol or meperidine for treatment of, rather than prevention of, vaso-occlusive crises. Not a study of a drug involved in the prevention if red blood cell dehydration

Wallen $2007 \quad$ Not a study of a drug involved in the prevention of red blood cell dehydration

Wambebe 2001 RCT of Niprisan, a naturally occurring compound. There is no evidence that any anti-sickling action is due to a reduction in dehydration of red blood cells

Weiner 2002

Study of nitric oxide. There is no evidence that the anti-sickling effect of the drug is due to a reduction in water loss through the red blood cell membrane

Wynn $2007 \quad$ Study of hydroxyurea, no measure of clinical outcomes of interest

Zago 1984 Trial of aspirin. There is no evidence that any anti-sickling action is due to a reduction in dehydration of the sickle red blood cells

RCT: randomized controlled trial 
DATA AND ANALYSES

Comparison 1. Anti-sickling drug versus placebo

\begin{tabular}{|c|c|c|c|c|}
\hline Outcome or subgroup title & $\begin{array}{l}\text { No. of } \\
\text { studies }\end{array}$ & $\begin{array}{c}\text { No. of } \\
\text { participants }\end{array}$ & Statistical method & Effect size \\
\hline 1 Mortality & 1 & & Odds Ratio (M-H, Fixed, 95\% CI) & Totals not selected \\
\hline $\begin{array}{l}2 \text { Number of other serious } \\
\text { sickle-related complications }\end{array}$ & 1 & & Mean Difference (IV, Fixed, 95\% CI) & Totals not selected \\
\hline 2.1 Overall & 1 & & Mean Difference (IV, Fixed, 95\% CI) & $0.0[0.0,0.0]$ \\
\hline 3 Quality of life measures & 1 & & Mean Difference (IV, Fixed, 95\% CI) & Totals not selected \\
\hline $\begin{array}{l}3.1 \text { Hospital stay per crisis } \\
\text { (days) }\end{array}$ & 1 & & Mean Difference (IV, Fixed, 95\% CI) & $0.0[0.0,0.0]$ \\
\hline 3.2 Loss of work days/crisis & 1 & & Mean Difference (IV, Fixed, 95\% CI) & $0.0[0.0,0.0]$ \\
\hline
\end{tabular}

\section{Analysis I.I. Comparison I Anti-sickling drug versus placebo, Outcome I Mortality.}

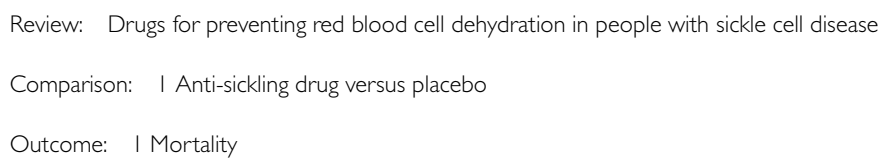

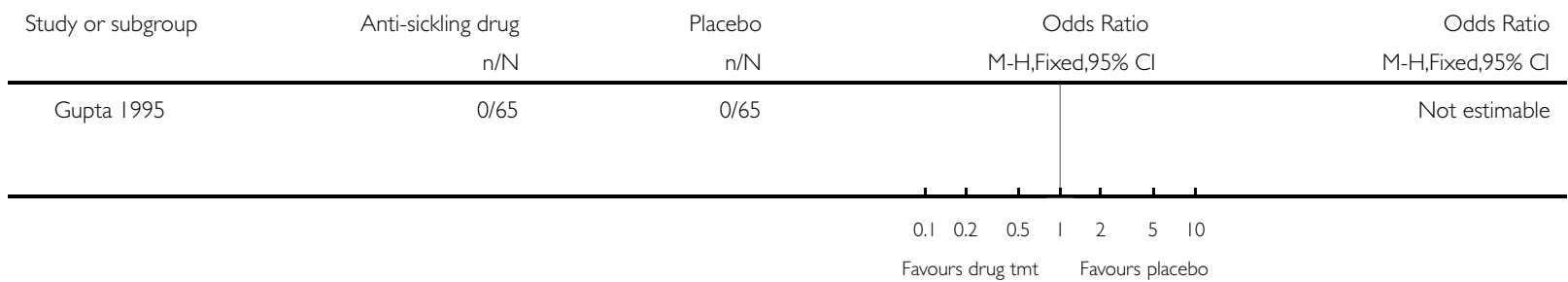


Analysis I.2. Comparison I Anti-sickling drug versus placebo, Outcome 2 Number of other serious sicklerelated complications.

Review: Drugs for preventing red blood cell dehydration in people with sickle cell disease

Comparison: | Anti-sickling drug versus placebo

Outcome: 2 Number of other serious sickle-related complications

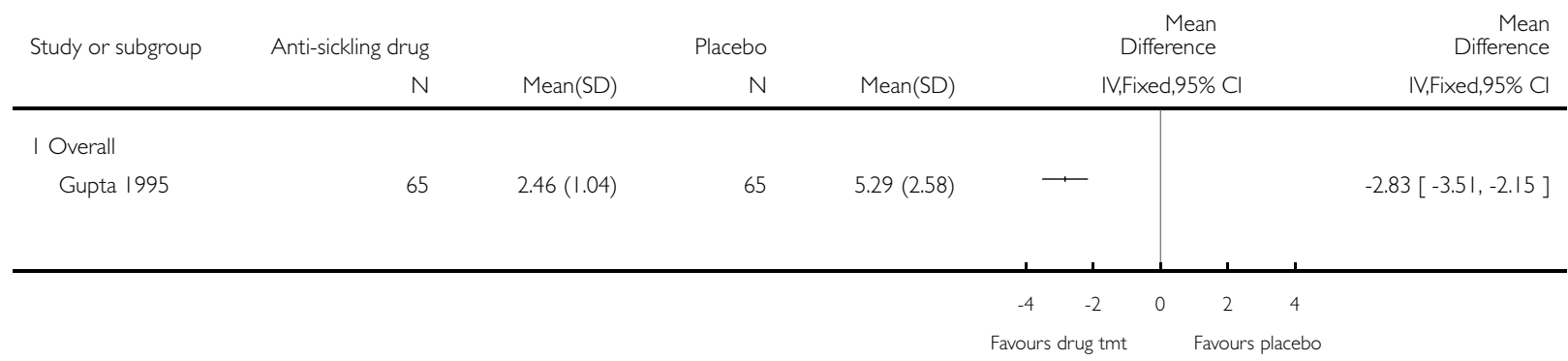

Analysis I.3. Comparison I Anti-sickling drug versus placebo, Outcome 3 Quality of life measures.

Review: Drugs for preventing red blood cell dehydration in people with sickle cell disease

Comparison: I Anti-sickling drug versus placebo

Outcome: 3 Quality of life measures

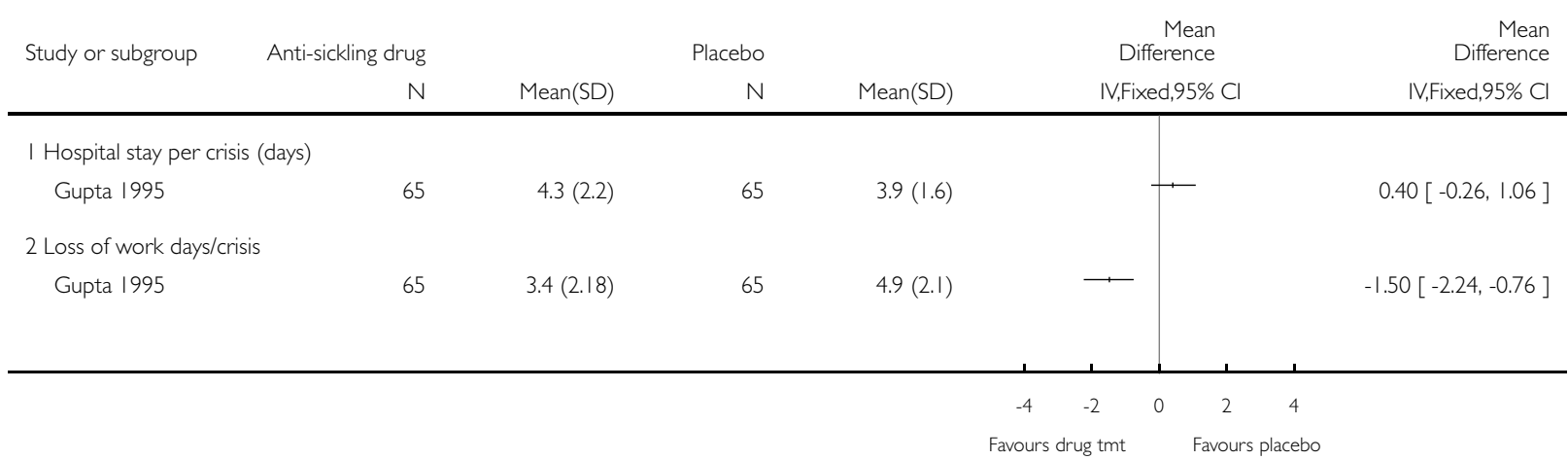




\section{A P PENDICES}

\section{Appendix I. Search of trial registries}

\begin{tabular}{l|l|l}
\hline Trial registry & Terms & Date of search \\
\hline WHO ICTRP & $\begin{array}{l}\text { "sickle cell dehydration" and "sickle cell red cell dehy- } \\
\text { dration" }\end{array}$ \\
\hline Clinical Trials.gov 2018 \\
\hline $\begin{array}{l}\text { "sickle cell dehydration" and "sickle cell red cell dehy- } \\
\text { dration" }\end{array}$
\end{tabular}

\section{WHAT'S NEW}

Last assessed as up-to-date: 18 October 2018.

\begin{tabular}{l|l|l}
\hline Date & Event & Description \\
\hline 18 October 2018 & New search has been performed & $\begin{array}{l}\text { A search of the Cochrane Cystic Fibrosis and Genetic } \\
\text { Disorders Groups Haemoglobinopathies Trials Register } \\
\text { identified 135 potentially eligible references, none of } \\
\text { which were eligible for any section of the review }\end{array}$ \\
\hline 18 October 2018 & $\begin{array}{l}\text { New citation } \\
\text { changed }\end{array}$ & \begin{tabular}{ll|l} 
A nequired summary of findings table has been included \\
in the review (Summary of findings for the main \\
comparison). All relevant sections of the review have \\
therefore been updated to incorporate the contents of \\
this new table \\
Given this is no longer an active area of research, this \\
review will no longer be regularly updated
\end{tabular} \\
\hline
\end{tabular}

\section{H I S T O R Y}

Protocol first published: Issue 1, 2002

Review first published: Issue 4, 2002

\begin{tabular}{l|l|l}
\hline Date & Event & Description \\
\hline 4 March 2016 & $\begin{array}{l}\text { New citation required but conclusions have not } \\
\text { changed }\end{array}$ & $\begin{array}{l}\text { We have made only minor changes to the text through- } \\
\text { out the review for this 2016 update }\end{array}$
\end{tabular}


(Continued)

4 March 2016 New search has been performed
We searched the Cochrane Cystic Fibrosis and Genetic Disorders Group's Haemoglobinopathies Trials Register and 28 references were identified; however, none were eligible for inclusion in any section of the review We will continue to run searches to identify any potentially relevant trials; however, we do not plan to update other sections of the review until new trials are published

19 April $2012 \quad$ New search has been performed

A search of the Group's Haemoglobinopathies Trials Register identified 34 references of which one has been listed as an included study (Ataga 2011) and three as excluded studies (Bartolucci 2009; Gladwin 2011; Uzun 2010).

19 April 2012 New citation required but conclusions have not changed

20 September 2010 Amended

11 November 2009 New search has been performed
A new study has been included in the review but did not lead to a change in conclusions (Ataga 2011).

Contact details updated.

A search of the Group's Trials Register identified eight new references which were potentially eligible for inclusion in this review

One new study was included in the review (Ataga 2008).

Seven of these have been excluded; four references were additional references to already excluded studies (Beatty 2007; Qari 2007; Weiner 2002; Wynn 2007) ; and three were references to new studies (Akinsulie 2005; Silva-Pinto 2007; Wallen 2007).

Through personal communication, we have details of a Phase III trial for which publication is pending (Ballas 2009). Full details will be included in a future update

11 November 2009 New citation required but conclusions have not changed

A new lead author ( $\mathrm{SN}$ ) has updated this review with the existing co-author (SB)

Converted to new review format.

4 September 2008 Amended

19 July 2007

New citation required and conclusions have changed

Substantive amendment.

A new review team has updated this review. Dr Priya C. Singh is now lead author with Dr Samir K. Ballas as co-author.

The former lead author, Ceri Hirst (née Riddington) , and former co-author Dr Lucia de Franceschi are no longer active authors on the review. 


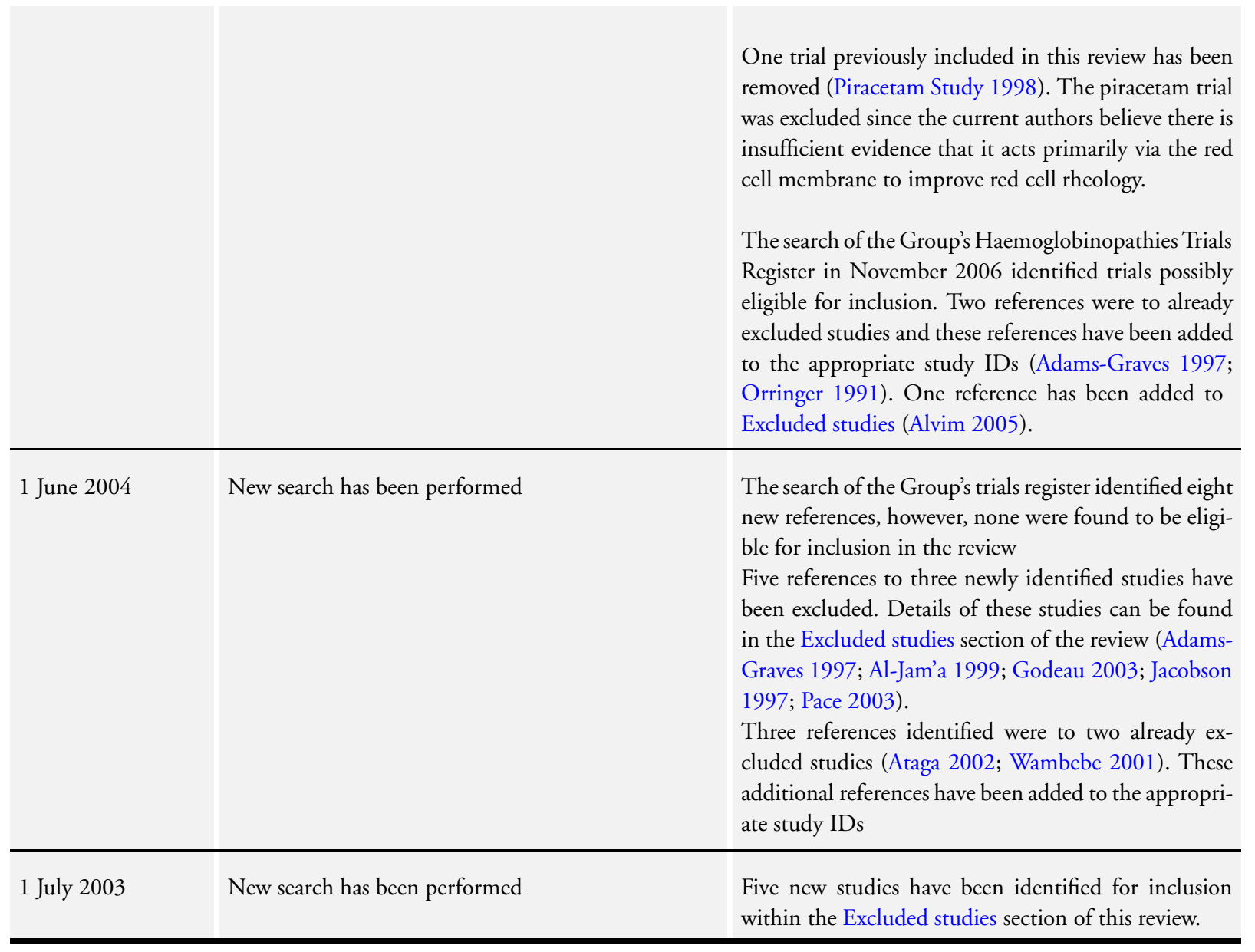

\section{CONTRIBUTIONSOFAUTHORS}

\section{Review from Issue 4, 2009}

Dr Singh has stepped down from the review team and Dr Nagalla is now the lead author for this review. Together with Dr Ballas, Dr Nagalla has updated this review and acts as guarantor for this and subsequent versions of the review. 


\section{Review from Issue 4, 2007}

Dr Singh is now lead author and updated the review with Dr Samir Ballas (co-author). Dr Singh acts as guarantor of the review. Dr Singh reviewed the current literature on piracetam and revised the manuscript with advice from Dr Ballas.

Drs Hirst and de Franceschi have stepped down as active authors on this review.

\section{Review up to Issue 3, 2007}

The review was conceived by the Cochrane Cystic Fibrosis and Genetic Disorders Group and designed by Dr Hirst (née Riddington). Dr Hirst and the Cochrane Cystic Fibrosis and Genetic Disorders Group conducted searches for relevant studies.

Dr Hirst and Dr de Franceschi screened, appraised and abstracted data for the review. Additional information from authors was sought by Dr Hirst were necessary.

Data entry was performed by Dr Hirst and interpreted by Dr Hirst with advice from the Cochrane Cystic Fibrosis and Genetic Disorders Group.

\section{DECLARATIONS OF INTEREST}

Both authors: none known.

\section{SOURCES OF SUPPORT}

\section{Internal sources}

- No sources of support supplied

\section{External sources}

- National Institute for Health Research, UK.

This systematic review was supported by the National Institute for Health Research, via Cochrane Infrastructure funding to the Cochrane Cystic Fibrosis and Genetic Disorders Group.

\section{INDEX TERMS}

\section{Medical Subject Headings (MeSH)}

Acetamides [*therapeutic use]; Anemia, Sickle Cell [*blood]; Antisickling Agents [*therapeutic use]; Clinical Trials, Phase II as Topic; Clinical Trials, Phase III as Topic; Dehydration [ ${ }^{*}$ prevention \& control]; Early Termination of Clinical Trials; Erythrocyte Aging [drug effects]; Erythrocytes [*drug effects]; Piracetam [therapeutic use]; Randomized Controlled Trials as Topic; Trityl Compounds [*therapeutic use]; Zinc Sulfate [* therapeutic use] 


\section{MeSH check words}

Humans 